Universidade de Brasília (UnB)

Faculdade de Economia, Administração, Contabilidade e Ciência da Informação e Documentação (FACE)

Programa de Pós-Graduação em Administração - PPGA

Nina Maria da Silva Neves Gadelha

\title{
Cultura organizacional no setor público - uma análise no Tribunal de Contas do Distrito Federal
}


Nina Maria da Silva Neves Gadelha

\section{Cultura organizacional no setor público - uma análise no Tribunal de Contas do Distrito Federal}

Monografia apresentada ao programa de PósGraduação em Administração (PPGA) da Faculdade de Economia, Administração, Contabilidade e Ciência de Informação (FACE), da Universidade de Brasília (Unb) como requisito parcial a obtenção do grau de especialista em Gestão de Pessoas.

Orientador: Professor Dr. MARCUS VINICIUS SOARES SIQUEIRA 


\section{SUMÁRIO}

1. Introdução................................................................................... 4

2. Referencial teórico......................................................................... 7

2.1. Peculiaridades da Cultura Nacional...................................... 8

2.1.1. Heranças de Portugal................................................ 8

2.1.2. Fazendo do nosso jeito............................................. 9

2.1.3. O brasileiro e o trabalho............................................ 12

2.1.4. A forma de se relacionar do povo brasileiro........... 13

2.2. A cultura das organizações brasileiras.................................. $\quad 20$

2.3. A cultura do setor público................................................... 26

3. Método............................................................................................. 36

3.1. Tipo de pesquisa..................................................................... 37

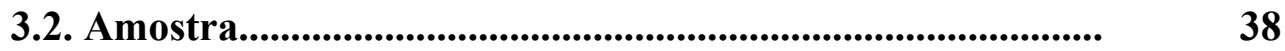

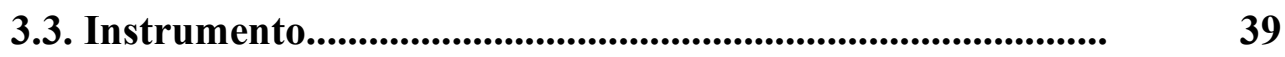

3.4. Análise dos resultados...................................................... 40

4. Apresentação dos Resultados.............................................................. 41

5. Discussão dos Resultados............................................................... $\quad 54$

5. Conclusão...................................................................................... 59

REFERÊNCIAS................................................................................ 61

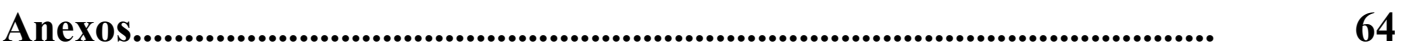




\section{Introdução}

O serviço público vem sendo marcado por mudanças sócio-culturais. As transformações no mercado de trabalho, a necessidade de transparência nas relações, as freqüentes intervenções da mídia e o próprio perfil do servidor, têm provocado impacto direto nas relações de trabalho. Em face disso, sob a perspectiva da prestação de serviços à sociedade, como, também na construção de novos mecanismos de governança, a qualidade da administração pública tem merecido atenção, notadamente, por meio da participação do cidadão nos assuntos e fatos relativos ao bem comum.

Nesse contexto dinâmico, as organizações, funcionários e indivíduos vêm alterando seus modos de pensar e agir, no sentido de estarem mais conscientes dos seus direitos e deveres. Surge, então, a necessidade de uma elevada capacidade de adaptação, aprendizado constante e eficiente. O órgão público não está fora destas demandas, ao contrário, há que estar presente, acompanhando o novo tempo. O serviço público está diante de cidadãos mais exigentes e atentos às questões que lhes dizem respeito. A partir daí, percebe-se uma sucessão de problemas decorrentes da tentativa de acompanhar o mercado. O principal problema que pretendemos analisar traduz-se na cultura organizacional sob a influência da cultura nacional ante as novas perspectivas.

O estudo da cultura organizacional no âmbito da gestão pública vem ganhando relevância à medida que avançam as necessidades de ajustamento às exigências do setor. A flexibilização das relações de autoridade e poder, a redução dos níveis hierárquicos, o melhoramento dos canais de comunicação e a interação entre os funcionários, ou seja, a redefinição dos sistemas de trabalho é medida freqüentemente adotada por órgãos públicos e tem merecido estudos e adaptações do ambiente organizacional e dos comportamentos dos servidores visando à conciliação dos esforços, na busca da satisfação do trabalhador, no alcance dos objetivos e metas pessoais e da entidade.

Segundo Motta (1997), a variação cultural refere-se primordialmente aos hábitos e comportamentos de um grupo ou sociedade para outros. Entretanto, é relativamente recente o estudo das formas que essas diferenças assumem no mundo do trabalho. O autor assevera que havendo uma relação direta entre a performance de uma organização e sua cultura, ou seja, se esta cultura organizacional carrega muito de nossa cultura nacional, a compreensão de nossas raízes se torna um ponto crucial no gerenciamento de nossas organizações. Desse modo, conforme preleciona Freitas (2007, p. 10), as mudanças no contexto mundial "revalorizaram e rejuvenesceram os estudos culturais, que assumiram maior complexidade e incerteza em 
relação aos próprios conteúdos, mas também em relação aos limites dos métodos de pesquisa mais interpretativos e indutivos utilizados na área."

O tema cultura organizacional ao longo dos anos 80 tomou nova forma e visibilidade, no entanto, nos últimos anos sua importância continua sendo reconhecida. Neste sentido impera, no momento, a definição ou delimitação da visão de cultura organizacional a ser aplicada nesse estudo, para que sob essa perspectiva sejam canalizados os trabalhos decorrentes da pesquisa. Várias têm sido as críticas acerca dos métodos de pesquisa utilizados no levantamento de informações sobre a cultura organizacional. A razão da desconfiança está no fato de o conceito de cultura organizacional não ser universal e de que esse elemento tornou-se panacéia para a resolução dos problemas organizacionais. Assim, sendo esse construto importado da antropologia faz-se necessária cautela no seu emprego em outras áreas de estudo.

Tendo em vista o interesse desta pesquisa podemos citar Saraiva (2002) que referenciando Wallasch assevera que a análise da cultura organizacional na esfera pública é naturalmente delimitada pelo espaço formal burocrático, no entanto, o fato de ser organizada por meio de regras de cunho impessoal, sua investigação permite a observação de uma complexa relação existente entre o processo normativo e o elemento cultural. A presente pesquisa utilizará preferencialmente a abordagem sistêmica aberta por oferecer mais subsídios para a compreensão da cultura organizacional do Tribunal de Contas do Distrito Federal à luz da cultura brasileira.

Os Tribunais de Contas são órgãos independentes que, por expressa disposição constitucional, atuam como auxiliar ao Poder Legislativo no exercício do controle externo da administração pública. As diretrizes gerais de sua organização estão definidas em sede constitucional. Da mesma forma, as atribuições e prerrogativas dos Tribunais estão fixadas na Constituição Federal de 1988 e fortemente valorizadas pela Lei Complementar no 101/2000 a Lei de Responsabilidade Fiscal.

$\mathrm{Na}$ perspectiva de autonomia e independência, prerrogativas da atividade é que estão fundamentados os interesses acadêmicos objetivos desse estudo. As questões relacionadas à cultura nacional, à conformação vigente do servidor mais antigo e a perspectiva criada pelo trabalhador que ora ingressa no serviço público, inseridas na cultura organizacional. Para solucionar esse questionamento examinaremos a cultura nacional, a cultura organizacional no serviço público e a cultura do Tribunal de Contas do DF.

O problema desta pesquisa é: Qual é a cultura organizacional do Tribunal de Contas do Distrito Federal à luz da cultura nacional? Na tentativa de dar subsídio para alcançar a 
resposta para esse questionamentos será necessário cumprir o objetivo geral é o de captar indícios da cultura organizacional do Tribunal de Contas do Distrito Federal à luz da cultura nacional, e objetivos secundários como caracterizar aspectos da cultura nacional, a cultura organizacional brasileira e a cultura organizacional do setor público.

O Tribunal de Contas do Distrito Federal (TCDF) atua no controle externo como auxiliar da Câmara Legislativa do Distrito Federal, na orientação e fiscalização de gastos do Governo do Distrito Federal, no uso adequado do erário e na verificação acerca da legalidade dos processos de admissão, exoneração e aposentadoria de servidores distritais.

A Missão do órgão é: exercer o controle externo da administração dos recursos públicos do Distrito Federal, em auxílio à Câmara Legislativa, zelando pela legalidade, legitimidade, efetividade, eficácia, eficiência e economicidade.

O organograma do Tribunal de Contas do Distrito Federal está estruturado sob o modelo burocrático, e, apesar das tentativas de modernização, ainda sofre muitas influências do princípio da unidade de comando e da centralização das tarefas, tornado o órgão menos afeto à flexibilização das ações. Possui 597 servidores efetivos, 60 servidores ocupantes de cargos em comissão sem vínculo, 40 servidores requisitados de outros órgãos, todos regidos pelo Lei $\mathrm{n}^{\circ}$ 8.112/90. O Colegiado é formado por sete Conselheiros, um Auditor e três Procuradores. A força de trabalho é composta ainda por estagiários e terceirizados.

Levantar indícios da cultura organizacional deveria ser a primeira providência de qualquer ação em gestão de pessoas, tendo em vista que avançam as necessidades de ajustamento dos contextos de gestão pública às demandas resultantes do processo de globalização. Os órgãos públicos têm implementado diversas ações com o intuito de modificação dos comportamentos dos servidores visando à conciliação dos esforços, na busca da satisfação do trabalhador, no alcance dos objetivos e metas pessoais e da entidade. No campo acadêmico os estudos sobre cultura organizacional ganharam corpo a partir dos anos 90 e ainda hoje têm sua relevância fincada no fato de que todas as atividades do gestor de pessoas estarão embebidas e de certa forma condicionadas ao contexto cultural presente em cada organização. 


\section{Referencial teórico}

\subsection{Peculiaridades da Cultura Nacional}

Fazer um estudo acerca do fenômeno cultura é caminho fértil, porém longo. Exige uma cuidadosa limitação do tema, tendo em vista sua extensão e inserção em todos os domínios das ciências sociais. Neste sentido não custa lembrar Laraia (1997), que em seu estudo antropológico sobre a cultura, citou Tylor que o definiu como contendo todas as possibilidades de realização humana, seus conhecimentos, suas crenças, a arte, moral, leis, costumes ou qualquer outra capacidade ou hábitos adquiridos pelo homem como membro de uma sociedade. Assim afirma DaMatta (2000), a cultura está nas ciências, letras e artes de um determinado grupo social.

No entanto, precisamos afunilar nosso conceito e a visão de Geertz (1989) pode ser muito útil, pois explica a cultura como um conjunto de mecanismos de controle para direcionar comportamentos, que vai além de padrões concretos de maneiras de agir ou de se comportar. Sugere, como descreveram Souza-Depieri e Souza (2005), que as relações sociais, assim como as institucionais são assinaladas por mudanças, pela aceitação subjetiva da ordem e pela lógica social que se manifestam ao longo do tempo e em função dos momentos

históricos. É nesse viés que tentaremos identificar, no percurso histórico da cultura brasileira, os traços pessoais ou disposição para comportamentos dentro do ambiente de trabalho.

Para Souza-Depieri e Souza (2005) os estudos sobre a cultura brasileira podem clarear o entendimento de fenômenos organizacionais, tendo em vista que esses não podem ser interpretados de forma apartada, mas, somente, a partir dos valores, hábitos, e ideologias sociais. Pois, como ensina DaMatta (2000), as pessoas aceitam alguns valores e consideram as ações humanas num modelo subjetivo. A cultura nessa perspectiva é algo vivo, pleno de reflexão e consciência, uma entidade que se movimenta entre o passado e o futuro. Para bem conduzir nosso caminho faz-se necessária a busca de um padrão que identifique o trabalhador brasileiro, para tanto, segundo DaMatta (2000 p. 12) é imprescindível a expressão da cultura na qual esse homem está inserido, "para que se possa sentir sua concretude e seu poder."

DaMatta (2000) acredita que uma cultura é forjada a partir de um universo de possibilidades, do qual cada grupo humano retira ou manifesta aquilo que lhe é possível, pois só pode pôr em prática algumas dessas possibilidades, associando-as a um leque de atributos especiais para por eles e com eles construir uma história particular. Assim cada sociedade apenas torna útil um número limitado de experiências concebendo algo único em termos 
culturais. A partir daí tem-se uma identidade social que qualifica o indivíduo como pertencente ou não, aceitante ou não daquela comunidade social. Porque a edificação de uma sociedade se dá por meio de afirmações e de negações na presença de certas situações.

A cultura encerra um estilo, um modo, um jeito próprio de fazer as coisas, por meio de escolhas - que de forma alguma são totalmente aleatórias -, algumas sim podem ser acidentais, porém, no mais das vezes, utiliza-se uma fórmula fornecida pela sociedade para traçar os perfis, assim, existem escolhas planejadas, construídas, inventadas e esperadas pelo grupo. E ambas organizam a memória da comunidade, mas são as intencionais que se prestam como formas pelas quais a sociedade cria e recria sua identidade social e suas tradições. (DAMATTA, 2000). Resumindo, cada grupo social possui ferramentas próprias para a construção de sua identidade cultural, esses instrumentos munem o indivíduo com o aparato necessário para sua distinção, tornando-o pertencente à determinada sociedade. Neste sentido vale então descrever qual foi o ferramental que nos entregou Portugal, para que perante nossas escolhas construíssemos o que somos como brasileiros.

\subsubsection{Heranças de Portugal}

Os traços da colonização portuguesa somados a outras experiências, como os fatores econômicos, políticos e sociais, foram progredindo na evolução da vida social do Brasil, formando uma identidade cultural nobre marcada pela criatividade, mas que pode burlar e obter favores utilizando um mecanismo para estabelecer, manter e controlar relações pessoais ou organizacionais. (SOUZA-DEPIERI e SOUZA, 2005). A avaliação de como e com que meios é construída a história cultural brasileira permitirá o estabelecimento de elos entre essa e sua manifestação dentro das organizações.

Como foi dito antes, dentro de uma série de possibilidades oferecidas a todas as sociedades, algumas são necessárias à própria sobrevivência e outras são acidentais. A descoberta do Brasil por portugueses é uma possibilidade eventual sobre a qual não se faz escolhas. (DAMATTA, 2000) Não obstante, segundo Holanda (1999, p. 40) a cultura nacional está associada a "Portugal numa tradição longa e viva, bastante viva para nutrir, até hoje, uma alma comum, a despeito de tudo que nos separa; o resto foi matéria que se sujeitou mal ou bem a essa forma".

Assim, a história brasileira está marcada por uma classe de indivíduos brancos e aristocráticos, por uma ordem social hierarquizada constituída num quadro nítido de valores discriminatórios. (DAMATTA, 2000). Porém, a tradição Portuguesa mesmo em Portugal não 
era muito rígida, dessa forma tudo que se conservou foi alterado ou abrandado pelas condições adversas do Brasil colonial. Deste modo pode-se identificar que tradições foram mantidas e servem para explicar traços tipicamente brasileiros como, por exemplo, a obrigação de ir aos ofícios embandeirados, com suas insígnias, às procissões reais, justificando o gosto do aparato e o dos espetáculos coloridos. (HOLANDA, 1999). Depreende-se das elocuções dos autores que a cultura brasileira está ancorada nas tradições portuguesas, no entanto, de lá só restou aquilo que se acomodou aos nossos meios de vida.

O brasileiro, nas palavras de DaMatta (2000), é um indivíduo marcado de forma indelével pela vida social hierarquizada, que não vislumbra que as pessoas podem mudar de lugar pelo próprio desempenho, assim têm mais valor o nome de família, o título de doutor, a cor da pele, o local onde mora, o padrinho, as relações pessoais, o ser amigo do Rei. Essa marca explica o porquê da descrença em modalidades de ascensão social que oferecem a mesma oportunidade para todos, tornando todos iguais. O brasileiro não admite uma forma meritória de crescimento, por sua vez, conforma-se mais com as idéias embutidas nos ditos populares de "filho de peixe, peixinho é" e "quem tem padrinho não morre pagão". Holanda (1999) sobre isso diz que o título de doutor confere ao seu portador tamanha distinção e relevância que esse poderá passar a vida modestamente sem que lhe exijam dedicação laboral intensa na busca por bens materiais, que submete e rebaixa a personalidade.

\subsubsection{Fazendo do nosso jeito}

Freyre (2004) explica que as tradições aqui sofreram afrouxamentos, e mesmo sendo as figuras senhoris ou superiores predominantes na formação social brasileira, nenhuma dessas predominâncias foi incondicional, pois freqüentemente observam-se casos de inversões e confusões de superioridades. Apenas no Brasil colonial uma mestiça clara, que se comportava e se vestia bem, tornava-se branca para todos os efeitos sociais. Essa característica traduz um povo que não crê em verdades absolutas, tendendo sempre a um meio termo que pode e deve ser alcançado dependendo da situação.

Para DaMatta (2000) também o Brasil é um país onde a lógica do dentro ou fora, do certo ou errado não funciona, ao contrário, o brasileiro apresenta dificuldade de ampliar esse dualismo de caráter exclusivo, ou seja, uma oposição que determina a inclusão de um termo e a automática exclusão do outro. Assim existe uma ideologia social brasileira que se legitima por estabelecer o intermediário e a síntese dos opostos como algo positivo. O que fica no 
meio, consente a associação e a negação das tendências e características antagônicas. Num exemplo caricatural do povo brasileiro, Freyre (2004, p. 793) destaca a figura do mulato:

Ao mesmo tempo que fácil o riso - um riso, não já servil, como o do preto, mas
quando muito, obsequioso e, sobretudo, criador de intimidade - tornou-se o mulato
brasileiro, quando extrovertido, transbordande no uso do diminutivo - outro criador
de intimidade. O desejo de estabelecer intimidade, tão característico do brasileiro, ao
qual está associado o pendor, tão nosso, para o emprego dos diminutivos - que serve
para familiarizar-nos com os objetivos. Serve principalmente para familiarizar-nos
com as pessoas socialmente mais importantes. Esse desejo de intimidade com as
pessoas nos parece vir, não só de condições comuns a todo povo ainda novo, para
quem o contato humano tende a reduzir-se à maior pureza de expressão, como
particularmente, de condições peculiares ao período de rápida ascensão de um grupo
numeroso, da população - o grupo do mulato - ansioso em encurtar, pelos meios mais
doces, a distância social entre ele e o grupo dominante. No uso brasileiro de
diminutivo, o mulato foi quem mais o enriqueceu de tendências e de significados
sociais particularmente brasileiros.

A intimidade do povo brasileiro, advinda da necessidade de aplicação de estratégias sociais de sobrevivência foi também observada por Gilberto Freyre (2004) que enfatiza que provavelmente em nenhum outro país da extensão do Brasil exista tanta mobilidade social entre classes e regiões. Assim qualquer brasileiro poderá conforme seu temperamento mais do que por suas características étnicas, encontrar muitas facilidades de ascensão social e política em outra região para onde se desloque. Essa mobilidade é devida, principalmente, por não serem tão rígidas psicologicamente as configurações de raça e classe social. Sob todas essas circunstâncias e em razão delas, o brasileiro tem uma noção destorcida de cidadania, a qual se sujeita a todo tipo de variação que perde seu caráter político universalista e nivelador. (DAMATTA, 1997) São elementos constitutivos dos traços brasileiros, portanto, a intimidade e a mobilidade sociais e a visão adulterada do cidadão.

Um estudo da sociedade brasileira requer um olhar atento às várias possibilidades que tanta diversidade encerra. Para DaMatta (2000), o povo brasileiro há que ser entendido sob vários aspectos e não sobre um único prisma ou princípio social. "A comunidade brasileira é heterogênea, desigual, relacional e inclusiva.” (DAMATTA 1997, p. 78) Isso devido a diversas fontes para classificação e filiação da população. Como uma sociedade relacional, o Brasil não possui um conjunto sistemático de comportamento predominante, baseado na cidadania, ao contrário possui muitos códigos de conduta operando simultaneamente e sem competição entre si. Daí, aquilo que uma norma não permite, outra pode conceder. (DAMATTA 1997) O conceito de cidadania exprime direitos e deveres em sua essência uma visão não muito clara dessa entidade tende a refletir em alterações desses dois princípios como será visto mais adiante. 
DaMatta (2000) soube bem traduzir o Brasil em sua cultura. O autor assevera que os rituais nobres dos palácios de justiça com leis que estabelecem as instituições dimensionam o Brasil, mas ele deve também ser caracterizado pela forma de adicionar à lei a pessoa e seus interesses pessoais, e assim desconsiderá-la em seu princípio. Da mesma forma Holanda (1999) diz que o caráter brasileiro tem afeição por normas fixas e leis genéricas, que abrangem a complexidade dos desejos. Percebe-se desta forma que a legislação brasileira de certa forma se submete à pessoa interessada para conceder-lhe direitos e isentar-lhe de deveres.

DaMatta (2000) fez da cultura nacional uma metáfora com a casa e com a rua onde operam leis distintas, num sistema em que às vezes não há comunicação entre ambas e onde as leis formais da vida pública não coincidem com as boas regras da moralidade que governam a honra e a lealdade para com os amigos, parentes e compadres. A partir daí esquematizou o que ele denominou de jeitinho e malandragem brasileiros, os quais possuem valor social à medida que promovem a possibilidade de junção harmônica dos espaços sociais. A validade da metáfora indicada é tão natural para o brasileiro, que mesmo leitor mais desatento entenderá seu significado latente.

Holanda (1999) sobre as casas portuguesas quando erguidas no Brasil colônia diz que deixaram de ser severas e sombrias, perdendo aspereza e ganhando varandas como acesso ao mundo de fora. Como tudo que veio para este país durante a colonização, as casas, os hábitos, as tradições, os valores tomaram uma forma própria que sempre traduz um particular dessa gente. Freyre (2004), por sua vez, destacou a casa-grande do engenho como moradia nobre e requintada e os sobrados em contraste com os mucambos residências dos simples, porém, em todas reinava uma ordem única de relação familiar. A casa para DaMatta (2000), é um lugar moral, onde o indivíduo se realiza na dimensão social. A casa é que determina o que são os brasileiros, sua honra, vergonha e respeito, ela exprime um emaranhado de símbolos que dá origem ao povo brasileiro. A casa contém o espírito harmonioso que impera sobre a confusão, a competição e a desordem. Na casa então pode-se tudo, todas a soluções oferecem contentamento, não há conflito.

A rua, ao contrário da casa, é o lugar de exploração onde prepondera a concepção negativa de cidadania e de trabalho. A rua, mais que um espaço físico, cria uma lente por meio da qual o mundo pode ser percebido e decodificado, nela predominam a desconfiança e a insegurança. A rua faz a mediação da casa com o trabalho, que para o brasileiro é concebido como castigo. (DAMATTA 2000). Segundo Holanda (1999) o povo brasileiro tem como característica a repulsa por toda moral fundada no culto ao trabalho. O contraste entre a casa e 
a rua feito pelo autor define no brasileiro o que há de bom ou ruim nesse mundo. Dessa forma, trabalhar é ruim, pois obriga a estar fora de casa, do aconchego, da segurança.

\subsubsection{O brasileiro e o trabalho}

Assim o brasileiro tem pouca disposição para o trabalho, diz Holanda (1999), mais ainda para o trabalho sem ganho imediato. Esse é um aspecto restritivo da disposição para grandes empreendimentos laborais. Existe um desejo de crescimento sem custo, de títulos, de posições e riquezas sem dificuldade, que reflete, ainda nos dias de hoje a deliberada busca por colocações indicadas em detrimento do esforço próprio. Essa característica do brasileiro é tão marcante que muitas vezes a motivação para o trabalho esgota-se na procura pelo modo fácil de ganhar. O brasileiro então, não possui motivação pelo trabalho em si. Sua vontade está na procura de um emprego que resulte bons salários e não que ofereça gratificação pessoal.

O trabalhador brasileiro desde os velhos tempos não emprega em sua lida rigor, método ou previdência, ao contrário a faz com desleixo e liberdade. No entanto, Holanda (1999) pondera que esse fato se dá não por falta de vontade mais pela conviç̧ão de que não vale a pena. Freyre (2004) atenta que a partir de determinado momento da vida nacional passou a ter maior prestígio a perícia técnica do descendente de escravo em detrimento da imperícia do descendente do senhor de escravo. Essa característica concedeu ao trabalho manual um tom desprezível, pouco digno em confronto com as atividades da alma. Havia maior valor no exercício da inteligência. As análises dos autores sugerem que o brasileiro não acredita no valor do trabalho, precisa antes, encontrar um meio de se sustentar sem suar a pele ou sujar as mãos, menos por incapacidade e mais por crença pejorativa sobre as atividades laborais.

Ademais disso, é fato conhecido que, no Brasil Império a vida era muito difícil e só embarcavam para estas bandas aqueles que não tinham nada a perder ou que eram obrigados a vir por vias legais. Assim, outro fator que influenciou o desgosto pelo trabalho foi o excessivo o gosto pela aventura. $\mathrm{Na}$ comunhão de fatores diferentes, raças, costumes e padrões de conduta da colônia de Portugal, acrescentando-se as condições tropicais que exigiam intensa adaptação, o gosto pela aventura foi elemento imprescindível que, além de predispor à mobilidade social, estimulava o indivíduo a enfrentar corajosamente as asperezas e resistências do lugar, criando as condições adequadas para o aventureiro. É dizer que a época reclamava ações audaciosas e recompensava bem os que assim agissem. (HOLANDA, 1999)

Holanda (1999) explica que o indivíduo trabalhador atribui somente valores positivos aos esforços que pratica, vendo como imorais as qualidades dos aventureiros. Para os 
aventureiros o objetivo final é o que importa, seu ideal é ter o fruto sem plantar a árvore. $\mathrm{O}$ trabalhador, ao contrário, é aquele para o qual o trabalho em si faz sentido. Assim esclarecida, durante a colonização do Brasil, coube à ética do trabalho, papel muito limitado, quase nulo. Pois as condições locais forçavam os métodos predatórios e dissipadores que, por sua natureza, exigiam energia persistente e metódica de superação, coisa muito rara nos nossos colonizadores, que passivos, logo se aclimataram, sucumbiram às sugestões do lugar e dos habitantes nativos, sem se preocupar em criar normas fixas e indeléveis de conduta. Mesmo nos trabalhos urbanos imperava amor ao ganho fácil e a inconstância que tanto caracterizam, no Brasil, os trabalhos rurais. Decididamente ao brasileiro restou a antipatia pelo trabalho exaustivo e a simpatia pela vida fácil e sem preocupações do aventureiro.

No trabalho o brasileiro não busca outra coisa além da própria satisfação, ele tem o seu fim nele mesmo e não na obra. As escolhas laborais, para esse indivíduo, são acidentais. (HOLANDA, 1999). Bem se apreende que o trabalhador brasileiro trabalha para se sustentar ou ganhar dinheiro e não para colher os louros da importância de sua produção laboral. Neste sentido Freyre (2004) afirma que o povo brasileiro, por natureza ou pelo clima não é dado a fazer exercício para desenvolver sua energia física e espiritual. Diz que permanece em casa, sentado a maior parte do tempo, não demorando por cair em estado letal de preguiça. E, além disso, que o sistema escravocrata criou em torno de si um ambiente de desonestidade nas transações e negócios que permeia de forma indistinta o imaginário brasileiro. Por fim o autor enfatiza uma limitação decorrente do ensino uniformizador dos padres da companhia, a saber, a capacidade de diferenciação, de iniciativa, de crítica e de criação. Numa visão bem pessimista, temos então um indivíduo que não gosta de trabalhar, não desenvolve atividades físicas, não possui consciência moral nas negociações e é limitado na capacidade de diferenciação, de iniciativa, de crítica e de criação.

\subsubsection{A forma de se relacionar do povo brasileiro}

Concordando com a limitação indicada por Freyre, Souza-Depieri e Souza (2005) asseguram, que passados 500 anos da colonização, é característica das organizações brasileiras a distância de poder, descrita por Hofestede, identificada pelo comportamento de espectador do funcionário subalterno sem autonomia, baixo senso crítico, baixa iniciativa e autodeterminação. Corroborando a visão negativa anterior, a caracterização de Hofestede oferece um indicativo válido do perfil do trabalhador brasileiro. 
Para entender um pouco mais sobre esse indivíduo torna-se necessária a avaliação dos meios como foram desenvolvidas as relações pessoais no decorrer do tempo. Souza-Depieri e Souza (2005) acentuam que a rede de relações estabelecida pela família patriarcal brasileira persiste no âmbito familiar e organizacional. Asseveram que a partir da relação dominador e dominado criada pelo senhor e seus escravos pode-se declinar as tendências presentes na cultura nacional. Essa relação de dominação era oscilante onde os escravos passavam de propriedade, para dependente, para protegido, indo até solidário e afim. Sua influência penetrava os lares e produzia uma dissolução da distinção social. (HOLANDA 1999) A partir desses modos de convivência da família brasileira torna-se perceptível sua influência na mobilidade social, na miscigenação, no coletivismo e a tolerância ao diferente.

A família nacional era tão peculiar em suas flutuações sociais e étnicas e em suas formas de organização, que se pode questionar o caráter predominantemente feudal, patriarcal, ou tutelar, da economia e da sociedade brasileira. No entanto, o patriarcado firmouse sociologicamente no Brasil, assim considerado na organização em forma e processos, não obstante terem os conteúdos econômicos e geográficos e as predominâncias étnicas e culturais lhe oferecido coloridos diversos. Isto porque aquilo que existia de mais resistente da aristocracia na organização patriarcal de família, de economia e de cultura sucumbiu ao amalgamento de raças e culturas contagiosamente democráticas e anárquicas, um tanto mais plástica que as duras formas iniciais. (FREYRE, 2004). Pode-se dizer que o patriarcado como sistema social também sofreu mutações em razão das contingências locais e das pessoas que para cá vieram, como tudo o que mais se produziu no Brasil, foi modificado para se adaptar as peculiaridades nacionais.

Curiosamente, Holanda (1999), obtempera que na esfera da vida doméstica da sociedade colonial os princípios de autoridade e obediência se firmaram mais que nos outros setores, não admitindo pressão de fora, o grupo familiar manteve-se imune de restrições ou abalos. A família colonial oferecia a idéia mais normal de poder, da respeitabilidade e da coesão entre as pessoas. Daí a predominância em toda a vida social os sentimentos inerentes vida familiar naturalmente particularista e antipolítica, uma invasão do setor público pelo privado, do Estado pela família. Vale então lembrar DaMatta (2000) que enfatiza que a casa invade as ruas mas que a rua não pode entrar em casa, definindo assim uma possibilidade de explicação para o predomínio do privado pelo público e não o inverso.

Segundo Holanda 1999, daí também, a preponderância dos vínculos biológicos e afetivos que unem ao patriarca seus descendentes, colaterais e afins, criados e agregados de toda sorte, sobre as demais considerações. As famílias tecem um todo indivisível, onde seus 
membros encontram-se associados, uns aos outros, por sentimentos e deveres, nunca por interesses ou idéias. Os vínculos afetivos formaram uma base sólida de convivência empregando regras, normas, direitos e deveres, que na falta de outro sistema também forte, se difundiu a quase todas as esferas sociais. Desta forma, inserido numa rede de parentesco, compadrio e amizade, dentro de casa, o brasileiro se torna pessoa, uma entidade dividida e relacional, cuja existência social se legitima por meio dos elos mantidos com outras pessoas num sistema de transitividade e gradações. (DAMATTA, 1997)

Esse tipo peculiar de família patriarcal influenciou inclusive o desenvolvimento urbano acarretando um desequilíbrio social cujos efeitos sustentam-se até os dias atuais. Dessa forma o brasileiro típico apresenta um fundo emotivo extremamente acentuado e transbordante o que leva a ser visto por estrangeiros como virtuoso na hospitalidade e na generosidade, um traço definitivo de seu caráter, mas que tem menos a ver com boas maneiras que com expressões de seu passado cultural. (HOLANDA 1999). É fato que a sociedade de uma forma geral sofreu a influência do sistema domiciliar. O lado positivo dessa ascendência se reflete no sorriso, no aconchego, na compaixão visível desse povo. No entanto, a institucionalização dos favores e privilégios se revela uma armadilha da qual não se pode, sem conflito, se desvencilhar.

Nesse sistema, as relações não são simples decorrência de atos, vontades e encontro individuais, elas constituem por muitas vezes o sujeito das situações. A ênfase nas relações pessoais advém do sentido que elas dão ao nosso mundo social. (DAMATTA 2000) De origem personalista a sociedade brasileira valoriza os vínculos de pessoa a pessoa, independentes e até exclusivos de qualquer tendência para a cooperação autêntica entre os indivíduos. No passado as agregações, mesmo que precárias, entravam em confronto com as lutas entre facções, entre famílias, entre regionalismos e faziam da vida social um todo incoerente e amorfo impondo assim, a acentuação do afetivo, do irracional, do passional, e o enfraquecimento das qualidades ordenadoras, disciplinadoras, racionalizadoras. (HOLANDA, 1999) Como dito antes não há ordem que se estabeleça sem harmonia de interesses coletivos, não há disciplina que perdure onde há privilégios ou razão que prevaleça sobre afeto.

O outro lado desse desequilíbrio social, conforme assegura DaMatta (2000) é que o brasileiro alterna entre um modelo nacional construído por leis universais onde o sujeito é indivíduo e situações onde cada qual se vira como pode, utilizando para isso o seu sistema de relações pessoais. O resultado desse sistema dividido e equilibrado entre duas unidades sociais básicas - o indivíduo e a pessoa - é que o primeiro moderniza a sociedade enquanto o outro a mantém presa à suas origens patriarcais. No sentido que de quando submetidos todos a uma mesma ordem social a possibilidade de progresso aumenta enquanto que, se para alguns 
a lei é menos severa, esses recebem benefícios e prosperam à custa daqueles que permanecem submetidos à lei, assim o crescimento é desigual.

O Brasileiro, enfatiza DaMatta (2000), tem consciência da alternância que predomina a vida social, dessa forma, desenvolveu em estilo de vida definido pela oscilação entre a rotina e as festas, mundo real e fantasia, trabalho e feriado. Mesmo na época do declínio do sistema patriarcal não havia extremos sociais ou de cultura. Os antagonismos nunca foram absolutos no Brasil, assim como não o são nos dias atuais. (FREYRE, 2004) Dessa forma, a sociedade tentou eliminar a tradição das leis implícitas, que podiam ser aplicadas ou não, criando um intermediário que estabelece um valor positivo à lei, de certa forma, negando-a. Foi instituída então, uma gradação legal onde são permitidas as interferências das relações pessoais as leis universais, e assim, dependendo do caso, a norma adquire nova interpretação que impede sua aplicação igualitária. (DAMATTA, 2000). Vê-se que não há lei dura e clara, ela sempre será maleável e obscura em suas entrelinhas. Não que a sua forma legal seja inadequada, mas haverá sempre uma outra forma de interpretação, que prevalecerá de acordo com o interesse da autoridade ou com as ligações sociais do cidadão.

Em outra oportunidade DaMatta (1997) dizia que aquele que se sujeita à lei no Brasil é o cidadão, aquele que não fazendo parte de uma rede de influência, se submete ao rigor da legislação. A família, os amigos e as redes sociais, por sua vez, estão rigorosamente fora da lei visto que são formalizadas política, ideológica e socialmente. As redes são universais e são instrumentos conscientes e positivamente valorizados como estratégias sociais, ou seja, institucionalizadas no Brasil onde convivem éticas distintas. Intrigantemente, o brasileiro aceita que fora das relações e da amizade existam leis inventadas para coibir ou até mesmo corrigir os abusos das redes de relações pessoais. Ou seja, o povo brasileiro gosta de leis e regras elas são muito úteis para resolver os problemas, mas os problemas dos outros, porque para ele próprio a solução vem por meio de sua rede de influências sociais.

Isto porque, no Brasil, o individualismo é criado com muito esforço, é visto de forma negativa e contra as normas que definem e emanam da totalidade. Assim o indivíduo isolado e sem relações, é também considerado negativamente. Pois se o cidadão não possui ligação com pessoa ou instituição de prestígio na sociedade, ele é tratado como um inferior. Mas se a categoria profissional tem uma ligação forte com o Estado então, eles podem ser diferenciados e tratados com privilégios. Assim sendo, obedecer às leis demonstra uma situação anonimato e inferioridade, comumente vista como sinal de ausência de relações, tão necessárias, pois revestem a pessoa de humanidade, tirando dela a condição de universalidade presente no papel de cidadão. (DAMATTA, 1997) É dizer que nesse país para ser 
reconhecido como pessoa, e então poder desfrutar das benesses da lei, o indivíduo há que necessariamente se vincular em grupos sociais.

Dessa forma considera-se normal que se concedam vantagens pessoais por meio de pessoas com as quais se possui relações de afeto, não é compreensível para o brasileiro, que um indivíduo que exerça qualquer função pública, deixe de prestar a amigos e parentes favores em razão de tal emprego. Mesmo as autoridades devem possuir sentimentos extremamente humanos. Por esse motivo, não há forma de haver aplicação rígida das normas judiciais ou de prescrições legais. É por gesto simples, sem controle ou intenção que o brasileiro foge à norma. $\mathrm{O}$ povo do Brasil é avesso às atividades lentas e demoradas, ou àquelas em que o sujeito esteja à mercê de um mundo distinto dele, o indivíduo não se submete deliberadamente a ser comandado por um sistema exigente e disciplinador. (HOLANDA, 1999) Essa característica tão marcante do Brasil à primeira vista toma um aspecto fortemente pejorativo, entender esse traço sem imprimir nele juízo de valor, é repensar toda sua história de desenvolvimento em suas peculiaridades.

Souza-Depieri e Souza (2005) enfatizam que o brasileiro vai ao encontro de alternativas de sobrevivência, não é somente ou deliberadamente burlar as normas, mas de criar outros espaços sociais, conciliando assim a regra jurídica que não necessariamente corresponde às demandas da sociedade, pois sua aplicação está voltada ao atendimento de interesses pessoais. É um procedimento social, tipicamente brasileiro de cumprir (ou descumprir) ordens absurdas, uma forma de harmonizar regras impossíveis de serem executadas com situações específicas. (DAMATTA, 2000) Também há esta questão, sobre o formalismo de nossas leis será tratado mais detidamente numa outra seção, quando tentar-se-á entender um pouco mais sobre como as coisas acontecem no Brasil.

Sobre esse particular, Freyre (2004) nos explica que, desde o Brasil colonial, as leis eram votadas não para serem rigidamente cumpridas, mas para a satisfação de exigências exteriores, sendo assim, bem marcada a atitude de simulação ou fingimento do brasileiro em relação ao cumprimento de regras que eram "para inglês ver." Então, perdura nos dias de hoje, que num confronto com a lei universal, evoca-se uma relação pessoal que permite dobrar ou romper a regra, tornando o impessoal personalíssimo, a favor da singularidade da relação. A lei existe e não é inútil, porém, não se aplica a casos específicos e muitas vezes, deve ser esquecida e o caso particular ressaltado por meio de um relacionamento pessoal. (DAMATTA, 1997) Esses autores procuram de alguma forma explicar, porque o brasileiro tende a ser desobediente às leis enfatizando que nossas leis desde sempre foram prescritas para poderem não ser cumpridas. 
A essa forma de driblar a lei DaMatta (2000) denominou jeitinho que é o jogo pacífico e legítimo de dar solução a entraves, incitando uma união da lei com a pessoa que a está utilizando. Trata-se de uma forma de congraçar interesses diversos, gerando uma relação aprovada entre o requerente, o funcionário e a norma legal. A conciliação acontece quando as motivações das partes são conhecidas, ou quando elas descobrem entre si laços comuns (amigos ou time de futebol), qualquer um que torne essa relação pessoal e possibilite a busca de uma resposta satisfatória e justa. Para Holanda (1999), nas necessidades o brasileiro sempre procurou o caminho mais certo de conseguir alguma coisa, é dizer, fazer da outra parte um amigo. Esse método é aplicado inclusive na prestação de serviços onde uma atitude imperativa ou de comando torna-se particularmente descabida. O jeitinho brasileiro é instituição reconhecida e não aprovada no exterior. Em nenhum outro lugar do mundo, faculta-se a obediência das leis, elas podem ser descumpridas, porém, não sem que se sofram as conseqüências desse ato.

De acordo com DaMatta (2000), o brasileiro considera lícito buscar alternativas para solução de seus problemas, na verdade esse ato é necessário e prático num sistema onde não existe o não absoluto em situações formais, mas sempre haverá um meio de conciliação. $O$ autor também examinou o reverso do jeitinho, quando se quer impor a autoridade sobre a decisão do funcionário. O "sabe com quem está falando?" também é institucionalizado no Brasil. A diferença é que esse evoca uma hierarquização entre o usuário e o agente da lei ao invés de uma relação amigável e fraternal. De qualquer forma é um questionamento desagradável e autoritário que tem a intenção de romper a regra sob a qual o usuário estaria subordinado (DAMATTA, 1997). Ambos formam um contínuo e se extremam na harmonização da solução dos problemas. (DAMATTA, 2000) Há ainda a figura do malandro criada por DaMatta (2000) que se traduz pela habilidade e sagacidade em não enfrentar a lei, mas apenas dobrá-la ou passar por cima dela. Ao malandro só caberá ter jogo de cintura perante a autoridade que utiliza a lei ao seu dispor.

Desenvolveu-se no Brasil esse estilo de navegação social justamente em razão da regulamentação não permissiva da legislação brasileira. Para conviver com essa situação o brasileiro descobriu e aperfeiçoou essa forma de conduta que permeia as entrelinhas das decisivas negações legais, a partir desses arranjos pode-se operar um sistema que não espelha a realidade social. (DAMATTA, 2000). Holanda (1999) afirma que a anarquia do brasileiro e a incapacidade de organização consistente representam a ausência de ordem legal efetiva. Pois o princípio da hierarquia que exerce forte influência sobre a vida social, é fundamentado necessariamente em privilégios. Da mesma forma, o princípio da obediência é hoje 
impraticável e daí resulta a instabilidade social. Assim segundo esse autor não vale a importação de sistemas sociais na tentativa de superação dos efeitos de desordem tão tipicamente brasileira. Mesmo porque uma cultura só absorve os traços de outra naquilo que se acomoda aos seus próprios meios de vida. O problema é que na falta de sistemas que se encaixem à peculiaridade brasileira, um após outro são importados os modelos gerenciais existentes, e que dão certo em outros lugares, e que são inadvertidamente aplicados a nossa realidade, sofrendo conseqüentemente, distorções como tudo quanto o que aqui tentou ser empregado.

Damatta (1997) sugere que a confusão entre as relações morais de intimidade e simpatia com uma relação puramente econômica, muitas vezes cria um conjunto de situações associadas a uma relação de trabalho onde o econômico está subordinado ao político e ao moral. Esse é um traço cultural que sugere acomodação e estabilidade. O desejo de proteção requer um ambiente de trabalho onde o privilégio está presente e culturalmente impregnado da influência das redes sociais de poder e amizade, reconhecida como o caminho para o sucesso social e profissional e para a garantia e a acomodação no trabalho. (SOUZADEPIERI e SOUZA, 2005) Vem, então, da confusão entre o social e o econômico a dificuldade que o brasileiro tem em não se valer de vantagem para alcançar sucesso profissional.

Como foi dito o brasileiro não tem ânimo para o trabalho, não consegue se organizar para se empenhar em atividade onde não vislumbre uma facilidade ou alta recompensa. A falta de capacidade de organização social decorre da carência da moral do trabalho e conseqüentemente, de ordem e de tranqüilidade entre os cidadãos, porque as duas são imprescindíveis para a harmonia dos interesses. (HOLANDA, 1999) E o fato não imbuirmos celebridade ao trabalhador, ou possuirmos a idéia de que o trabalho é local onde se pode honestamente enriquecer e ganhar dignidade, confunde as relações entre patrões e empregados. Essas relações que vão do econômico ao moral, misturando o que é puramente econômico com laços pessoais de simpatia e amizade, atordoam o empregado e permitem ao patrão exercer controle da situação. (DAMATTA, 2000) E assim se perpetuam também nas relações profissionais o protecionismo ou a retaliação comum das relações pessoais gerando um círculo vicioso de favores e recompensas que, por sua vez, fomenta as diferenças sociais. Por tudo que se viu, nota-se que a cultura nacional é bem peculiar possuindo características facilmente identificáveis que se infiltram em todas as áreas sociais. Na busca de descrições acerca dos modos de agir e pensar do servidor no Brasil e da análise de como a cultura 
nacional influencia esses modos, passaremos a seguir ao estudo mais pormenorizado da cultura organizacional brasileira e do setor público.

\subsection{A cultura das organizações brasileiras}

A cultura permeia o universo da existência humana e está também presente nas partes desse todo. Os grupos sociais, famílias, comunidades, empresas e etc., desenvolvem suas próprias culturas que sempre estão impregnadas pela cultura maior na qual o grupo está inserido. Segundo Motta (1997) a cultura pode ser entendida como uma forma de comunicação ou um conjunto de símbolos e sinais utilizados para dar sentido ao mundo. Ela freqüentemente ordena a sociedade de forma torná-la única, classificando em grupos distintos os membros da comunidade.

Neste sentido, Freitas (1997) assegura que a cultura de uma organização é fortemente influenciada por seus fundadores, líderes, pelo seu processo histórico e pelo mercado no qual está inserida, assim como pela cultura nacional. Para essa autora, toda organização é formada a partir de comportamentos e representações advindas dos valores, crenças e mitos valorizados naquela cultura. Sua estrutura formal é reforçada dialeticamente pelas relações interpessoais diárias somadas a tudo quanto houver de concreto que compõe o mundo material da empresa que está profundamente relacionado à história e à formação etnológica da cultura a que pertence à organização. A cultura local então penetra na cultura organizacional dando-lhe contornos próprios, porém, não muito afastados dos valores já assimilados pela comunidade maior.

Nos ambientes das organizações, conforme nos explicam Silva e Zanelli (2004) a cultura há que ser entendida como uma variável organizacional, algo que a organização tem, ou como uma metáfora, o que a organização é. Para Robbins (2002) a cultura organizacional se refere a um sistema de valores, compartilhado pelos membros e que difere de uma empresa para outra. Edgar apud Cavenon (2004), por sua vez, entende que a cultura organizacional é o produto do trabalho dos indivíduos que aplicam, testam, desenvolvem e validam procedimentos que, tendo funcionado bem, são ensinados aos demais membros do grupo como a forma certa de perceber, pensar e sentir determinadas situações. A cultura abrange todas as possibilidades de relacionamento entre o indivíduo e o meio influenciando-os e sendo influenciada por eles.

Da mesma forma Freitas (1997) afirma que nas organizações a cultura é fundamental para seu sucesso posto que, oferece princípios básicos, que são pré-conscientes e tomados 
como verdadeiros, e se transformam em valores diários. O sistema de valores é consciente e, por sua vez, cria modelos de conduta, formas de pensar e maneiras de agir próprios da instituição.

As empresas brasileiras têm suas culturas embebidas da cultura nacional. Segundo Carbone (2000) a cultura organizacional está em permanente movimento, porém ela circunda um eixo estabelecido pelo tempo e pela história. A cultura, então, é adaptável e pode ser submetida a uma nova ordem, porém ela nunca poderá ser totalmente modificada. A cultura organizacional brasileira, de acordo com o autor, é forte o suficiente para desvirtuar as formas de aplicação dos processos e para influir profundamente nas tentativas de mudança. Como não poderia deixar de ser, as organizações nacionais têm seu funcionamento atravessado pela cultura brasileira e muitos de seus traços refletem visivelmente essa influência.

O brasileiro é reconhecidamente relacional, esse traço social, em si, já revela uma faceta do funcionamento das organizações no Brasil, pois para Carbone (2000) há poucas possibilidades de avanço para empresas inseridas num mercado competitivo, quando as condições sociais locais apresentam imperativo onde as relações interpessoais são mais importantes que a lei e a ordem estabelecidas, como ocorre neste país. Neste sentido as empresas precisam ser extremamente flexíveis e adaptáveis à maneira de agir e pensar do povo brasileiro. De acordo com Vieira e Carvalho (2003) as ações e estruturas organizacionais devem corresponder às pressões ambientais assim como atuar em conjunto com os outros atores sociais para subsidiar e reforçar a construção do contexto constitucional.

Vieira e Carvalho (2003) asseveram que as organizações procuram conformar suas estruturas e ações aos valores do ambiente, para alcançar legitimação social aumentando assim suas chances de sobrevivência. Esse fenômeno é chamado de conformidade ou isomorfismo. Para alcançar o equilíbrio com o ambiente a empresa pode utilizar mecanismos de coerção, de imitação e/ou normativos. Essas ferramentas estão relacionadas à manutenção ou à mudança de valores e práticas culturais em razão de pressões advindas do contexto institucional mais amplo, ou de transformações estruturais nas relações de poder entre entidades sociais, de conflitos de interesses entre grupos sociais, inovações tecnológicas significativas, e muitas outras. Essa é uma característica freqüentemente observada nas multinacionais que ao se instalarem no Brasil sofrem um choque cultural seguido do processo de aculturação para se ajustarem ao jeito brasileiro.

As normas brasileiras são muito específicas e o ajustamento das organizações se configura a partir da reinterpretação das leis e seu resultado dependerá das partes incluídas na questão. (PRATES, 1997) Assim no Brasil podem existir regras escritas que são ignoradas ou 
desconhecidas pela comunidade, ou que não se aplicam à realidade, esses fatores são indicadores do formalismo. O formalismo é a discrepância entre o prescrito e o usual. Nestes casos as leis passam a ser desrespeitadas sem a conseqüente aplicação das sanções previstas. Esse fenômeno se caracteriza pela criação de uma regra formal que não será aplicada efetivamente na prática e não surtirá o efeito desejado sobre o comportamento. (VIEIRA E CARVALHO, 2003) O comportamento organizacional é normalmente decorrente do costume e da navegação social típica do nativo para driblar as regras e para enfim, ser definido pela sanção como forma de evitação de punições.

Para Prates (1997), dessa forma há uma separação entre o direito e o fato, característica do formalismo, que o justifica quando os processos de ajuste surgem para superar a dicotomia. No entanto, pode prevalecer o lado doentio do formalismo, onde os processos permitidos atingem formas como o nepotismo, favoritismo e suborno gerando instabilidade e insegurança. Na verdade, ocorre uma aceitação tácita de normas, mas sua prática é distorcida, em razão de outros elementos culturais mais ativos e presentes no comportamento do brasileiro. Isso pode ser associado a uma estratégia de mudança social determinada pelo caráter dual formação histórica do brasileiro e do modo particular como ele se articula com o resto do mundo. Como vimos em outra seção há no Brasil uma 'mania' na imposição de normas sociais que nem sempre são criadas para serem cumpridas, mas somente para oferecer justificativa factual.

As organizações brasileiras sofrem com o excesso de regras e com o jeitinho de burlar as normas, daí elas precisarem administrar o cumprimento das leis com a rede de articulação social. O formalismo impõe que as organizações brasileiras se submetam a aplicação usual de instrumentos de determinação legal ou pelo surgimento de novas regras ou por mudanças na legislação vigente. (VIEIRA E CARVALHO, 2003) Assim como na vida social, a flexibilidade das organizações perante a regra ocorre porque o formalismo acontece na presença de lealdade entre as pessoas. De um lado há o aparato legal idealizado e do outro uma trama de relacionamentos fundada na lealdade entre as pessoas que ao ser acionada procurará uma solução para os objetivos individuais. (PRATES, 1997) No Brasil, segundo Vieira e Carvalho (2003) é possível que corporações mais fortes consigam vantagens por meio de seus conhecimentos e de pressão junto ao legislativo, numa rede de relações e favores que administra em benefício próprio em detrimento dos interesses públicos.

Por outro lado, de acordo com Vieira e Carvalho (2003) as organizações freqüentemente não crêem na efetiva aplicação de uma nova lei, nessas condições as adaptações são provisórias ou desconsideradas até que as sanções previstas comecem a ser aplicadas. $\mathrm{O}$ 
formalismo é componente inerente da cultura nacional em razão da formação sociocultural do brasileiro. Esse elemento atua como mecanismo institucional coercitivo de mudança cultural. Predomina no Brasil a lógica da norma e da sanção legal. O formalismo foi instituído ao longo dos anos e se presta como agente regulador na construção e na compreensão da dinâmica social. As organizações brasileiras possuem uma dinâmica específica fundada na norma da lei para inglês ver. Isso explica (porém não justifica) as maquiagens realizadas em organizações que aparentam estar atuando legalmente quando não estão.

A formalidade como característica das organizações brasileiras decorre da falta, em seus primórdios, de um povo. Para estabelecer suas instituições os construtores do novo mundo não tinham em quem se basear, senão naquilo que já existia em outros lugares. Assim utilizando o formalismo como ferramenta de construção nacional o Brasil partiu da teoria para o costume, do formal para o vivido, sem a preocupação com os impactos sociais decorrentes das diferenças culturais da população. (VIEIRA E CARVALHO, 2003) Os regimes sociais eram impostos por meio de leis criadas aos costumes importados, que nem sempre correspondiam às necessidades do Brasil colônia, o método, no entanto, continuou a ser utilizado e foi institucionalizado. Em razão disso conforme dizem Vieira e Carvalho (2003) ao longo de sua formação o Brasil tem apresentado uma conformação em suas condições internas de funcionamento e outra forma aparente em articulação com o mundo. O formalismo, mesmo deixando de ser imposição de Portugal, continua protagonista na importação de modelos institucionais dominantes em outros países e na aplicação formal de tais sistemas na tentativa de transformação e manutenção sociais

Referenciando Hofestede, Motta (1997) diz que as decisões tomadas nas empresas brasileiras são caracterizadas por intensa interação social, assim como pelo envolvimento de superiores autocráticos revelando uma sociedade coletivista, com alta distância do poder e que busca evitar a incerteza. Essas decisões buscam mais adquirir vantagens que ter oportunidade limitando-se a informações de obtenção fácil. O estudo de Hofestede é emblemático e em suas conclusões reafirmam nuances da impregnação da cultura organizacional pela cultura nacional.

O autor segue comparando a distância de poder no Brasil com a distribuição de renda nacional e o passado escravocrata exibindo traços de exploração de recursos, do consumidor, do meio ambiente e de desperdício. Ele diz que:

O colonizador, que se apropriou da cultura indígena, principalmente por meio da índia; o colonizador que se apropriou da cultura negra, em um modo de produção, o capitalismo, que não pressupunha a escravatura, é hoje o burguês ou o tecnocrata, que 
se apropria da força de trabalho. No Brasil, o operário é o sucessor do escravo. (Motta, 1997 p. 31)

Freitas (1997) por sua vez, definiu que no âmbito organizacional os traços culturais mais influentes são a hierarquia, o personalismo, a malandragem e o aventureiro. Para cada traço que indicou, a autora determinou o caminho social que ela seguiu para se estabelecer como forma de conduta da empresa nacional. A hierarquia, ela explica que decorre da força de trabalho escravo, ordenado e reprimido, numa estratificação social rígida estabelecendo grande distância de poder. Por outro lado o patriarca que cria em torno de si uma rede de protecionismos geradora de valorização nas relações sociais. A hierarquia é observada na unidade de comando forma administrativa que prevalece na burocracia.

Para o personalismo a autora observou a implementação de uma nova ordem social redefinida econômica, política e socialmente pelo fator de distribuição de privilégios e favores. Em razão disso a unidade básica no Brasil é a relação que modifica e cria variações da cidadania. A malandragem surgiu em função do tratamento desigual entre os indivíduos que aperfeiçoaram um modo de navegação social que permite ao brasileiro ser mundialmente conhecido como adaptável, original, dinâmico e flexível. A figura do aventureiro provém da dignificação da ociosidade em detrimento do trabalho braçal que era tarefa exclusiva de escravo. (Freitas, 1997) Para definir esses traços a autora se valeu dos estudos de DaMatta sobre a cultura brasileira utilizando-os como parâmetro determinar a linha de desenvolvimento do perfil da cultura organizacional.

Sobre alguns desses traços Prates (1997) afirma que o brasileiro possui cultura baseada na concentração de poder, no binômio hierarquia/subordinação, calcada na força militar tradicionalista e no poder racional-legal, para a implantação e perpetuação da autoridade. Destaca-se no cotidiano brasileiro o trabalhador que possui, mais que especialização, o magnetismo no discurso ou poder nas relações interpessoais que configura o caminho natural na resolução de problemas e na obtenção de privilégios. No provimento de cargos ou lugares nas organizações e no mercado de trabalho tende a ser nepotista, ou seja, na luta por um espaço organizacional ou social mais valem os critérios de propriedade e de pertencimento. (MOTTA, 1997) Essas observações levam à confirmação do pressuposto de impregnação da cultura maior na sub-cultura. As relações profissionais estão marcadas pelas ocorrências dos mesmos traços identificados nas relações sociais.

Sobre outros aspectos da cultura organizacional nacional Prates (1997) considera que o paternalismo exerce controle sobre o indivíduo e em contrapartida oferece oportunidade de identificação e pertencimento ao grupo recompensando com alto grau de segurança. No Brasil 
o poder externo é referência para o indivíduo. Esse perfil cultural resulta na postura de espectador, com vertentes de mutismo e baixa consciência crítica, baixa iniciativa, pouca capacidade de realização por autodeterminação e de transferência da responsabilidade como qualidade do trabalhador brasileiro. (PRATES, 1997) O paternalismo pressupõe infantilização do empregado que dependerá profissionalmente e afetivamente do empregador, mesmo numa condição de maior autonomia e liberdade.

O sistema patrimonialista juntamente com os longos períodos autoritários na formação sociocultural do Brasil e com as estruturas de poder vigentes, o modelo de representação política, o nível educacional e a baixa capacidade empreendedora da população, e o conceito precário de cidadania, resultam no uso freqüente de mecanismos coercitivos de manutenção e de transformação social. (VIEIRA E CARVALHO, 2003) Dessa forma, na cultura brasileira caminham lado a lado, o patriarcalismo supridor e afetivo e o patrimonialismo hierárquico e absoluto. (PRATES, 1997) A ambigüidade vivida pela cultura do Brasil província estende-se para todos os ramos da sociedade atual exigindo o uso alternativo de navegação social, o jeitinho brasileiro.

Sobre a aplicação de técnicas coercitivas para mudanças culturais, Freitas (1997) entende que na prática os modelos de gestão aplicados nas organizações brasileiras são trazidos por empresas multinacionais ou importados de modelos teóricos. Essas práticas gerenciais por serem baseadas em outras culturas têm pressupostos e valores diferenciados e conflitantes com a cultura local. Vieira e Carvalho, (2003) concordam e acrescentam que as leis impostas de fora para dentro são de assimilação lenta e penosa, dessa forma, não são cumpridas e desencadeiam um processo dinâmico de criação de normas que reforcem as regras já criadas e não obedecidas. As mudanças na cultura organizacional das empresas brasileiras exigem atenção aos processos sociais e adaptação dos sistemas aos costumes mais enraizados sob pena de não se tornarem efetivas.

Segundo Carbone (2000), no Brasil, as mudanças culturais são facilitadas pela flexibilidade, mobilidade, mutabilidade e alta criatividade na solução de problemas. As organizações, como os próprios brasileiros, têm boa capacidade de lidar com a diversidade, de conviver com o ambíguo, de procurar saídas inusitadas, por meio de relacionamentos complementares e afins e principalmente, de desenvolver um clima de trabalho cooperativo, alegre e favorável. Por outro lado os elementos que entravam as mudanças culturais nas organizações são a burocracia, o autoritarismo, a aversão ao empreendedor, o impulso em levar vantagem e o reformismo presentes nas instituições nacionais de uma forma geral. É dizer que muitos traços culturais brasileiros permitem uma adaptação rápida em casos de 
mudanças, no entanto, devem ser levados em consideração aqueles costumes que sempre obstaculizaram as alterações e até a evolução das organizações no Brasil especialmente as públicas. Não muito distante da iniciativa privada a cultura do setor público também sofre influência das características típicas da cultura nacional como pode-se observar no capítulo que se segue.

\subsection{A cultura do setor público}

Holanda (1999) afirma que o predomínio incessante dos interesses individuais sobre uma ordenação impessoal, formou um modelo obrigatório para todas as composições sociais do Brasil, ocorrendo mesmo nas instituições democráticas, fundadas em princípios neutros que pretendem dispor a sociedade em normas universais. Nesse entendimento é negada a possibilidade de também nos negócios públicos de haver qualquer sentido construtivo ou positivo, virtudes como probidade, sinceridade, desinteresse pessoal já não eram próprias dos políticos brasileiros de outrora. Daí surge o estereótipo negativo do funcionalismo brasileiro. Não há cidadão que não se aborreça ou imediatamente utilize seus mecanismos de navegação social, quando se vê obrigado a intercurso com uma agência governamental.

Segundo Freyre (2004) naqueles tempos os serviços públicos eram mais zelosos em atenderem interesses particulares que em favor do bem público. Os agentes de governo longe de coibirem abusos, eram os atores da prática da resolução das vontades individuais. Por outro lado, se fazia impossível aos detentores de posições no governo, criados nesse ambiente, compor distinção essencial entre os domínios do privado e do público. Nesse sentido Holanda (1999) disse que esses servidores caracterizavam o que se chama de funcionário patrimonial onde a própria gestão das funções, dos empregos e dos benefícios relaciona-se a direitos particulares e não aos interesses objetivos da burocracia pura definida por Weber. O funcionalismo patrimonial brasileiro, com a divisão das funções e com a racionalização, adquiriu traços burocráticos. Mas em sua essência ele é diferente desse sistema. Esse é um exemplo daquilo sobre o qual se discorreu acima. O princípio puro pode funcionar, mas após ganhar feições brasileiras fica tão deturpado que não se presta para implantar adequadamente como sistema.

As dificuldades observadas desde a colonização no funcionamento do setor público podem ser atribuídas à expansão improvisada da burguesia urbana no Brasil, pois as atitudes peculiares ao patriarcado rural se difundiram em todas as classes, tornando-se norma aceita de conduta pessoal. Assim ante a falta de burguesia independente, os candidatos às funções 
públicas eram recrutados entre aqueles indivíduos da comunidade dos senhores rurais, condicionados àquele tipo de atuação, em conseqüência, toda a ordem administrativa do país durante o Império e a República contém elementos ligados ao velho sistema senhorial. (HOLANDA, 1999) Neste sentido o Brasil está historicamente fadado perpetuação das antigas maneiras, no entanto, uma nova ordem social, advinda principalmente da economia mundial, empurra o brasileiro contra sua cultura e exige reorganização para o crescimento, mais isto será assunto para outra ocasião.

Dessa forma, conforme afigurou Holanda (1999) perduram as buscas pelos meios de vida definitivos, que oferecem segurança e estabilidade em troca de um mínimo de esforço pessoal, de aplicação e de sujeição como acontece ainda nos empregos públicos. No entanto, segundo DaMatta (1997) esses processos sociais tipicamente brasileiros têm conduzido uma convivência inquieta tanto para os indivíduos mais conscientes da sociedade como para as teorias da justiça social. Da mesma forma, começa a incomodar a estrutura do favor como uma instituição nacional, característica das sociedades relacionais, em detrimento de uma experiência social mais individualizada observada na atualidade.

Vieira e Carvalho (2003) asseguram que na administração pública, um fenômeno organizacional recorrente no Brasil tem a ver com as formas de navegação onde o setor público é substituído por mecanismos de autoridade e de competência política, o chamado clientelismo. Segundo Chanlat (2002) a administração burocrática é uma importante ferramenta política e ética nos regimes de democracia. Em sua essência ela separa a coisa pública daquilo da ordem moral privada. Porém a dificuldade de implementação da burocracia em sua essência no Brasil decorre do fato de que nessa sociedade mais vale o espontâneo, as relações pessoais, os laços de integração que as tentativas racionalistas de articulação da área pública. (VIEIRA E CARVALHO, 2003) Assim a cultura brasileira só aproveitou da burocracia weberiana aquilo que não ofendeu os costumes. Um país relacional não permite que existam interesses universais que se configurem mais importantes que os interesses da rede social.

Como num ciclo perpétuo a influência do patriarca toma novas formas, ajustando-se a uma nova realidade, porém, permeia de forma reconhecível todos os sistemas administrativos impostos no Brasil. Vieira e Carvalho (2003) afirmam que na passagem do patrimonialismo para a administração burocrática manteve-se a força do quadro político brasileiro, onde o coronelismo deu lugar ao clientelismo e ao fisiologismo, e continuou entremear a administração do Estado. Assim há resquícios da administração patrimonial visíveis em postos públicos cativos de clientelas de grupos políticos ou econômicos. 
No momento, consoante Vieira e Carvalho (2003), o modelo burocrático não atende mais as necessidades do mercado, ele não faz sentido e nova mudança vem sendo imposta, agora para o modelo de administração pública gerencial. A nova reforma da administração brasileira pretende aumentar a eficiência e a efetividade das agências estatais; fortalecer o Estado na promoção do desenvolvimento econômico; assegurar um serviço público orientado para o cidadão e responsabilizar o servidor pelos seus resultados. A reforma do sistema administrativo brasileiro está em andamento e pode ser visualizada já em alguns setores da administração. Como em outras ocasiões, regras vêm sendo criadas para a adaptação dos serviços públicos às novas necessidades emergentes.

Chanlat (2002), referindo-se ao serviço público de uma forma geral, assegurou que o gerencialismo configura a transferência de princípios, valores e procedimentos da administração da esfera privada para o setor público. Essa transferência não leva em consideração suas peculiaridades, assim, essas mudanças não se efetivarão sem problemas e os numerosos empregados dos serviços públicos ficarão perdidos nesses novos discursos. O serviço público não é comparável em sua natureza a uma empresa privada. $\mathrm{O}$ autor se refere à aplicação da nova ordem a todo o serviço público mundial e assevera que haverá problemas em sua implantação, que dirá no Brasil onde as normas privilegiam os que possuem rede de relacionamento mais influente.

Vieira e Carvalho (2003), afirmam que no Brasil as reformas antecedem os costumes, assim, as leis antecipam as práticas. A aplicação de leis e não de comportamentos usuais para estabelecer mudanças sociais geram descompasso. Tornou-se mais fácil adotar modelos ou padrões, que são funcionais administrativamente em outras instituições, por meio legal, que institucionalizar um comportamento social. No entanto, como não são consideradas as particularidades culturais, a adoção de leis manifestas estranhas ao real trabalho administrativo pode configurar a constituição de fachadas administrativas enquanto o verdadeiro trabalho continua sendo conseqüência do comportamento usual, característica das antigas instituições. Em alguma medida o comportamento do brasileiro tem sido influenciado pela visão da globalização que vem impregnada de uma cultura mundial menos relacional, mais voltada para a transparência nas atividades e mais preocupada com a limitação entre o espaço público e privado.

As organizações no Brasil, de uma maneira geral, possuem características aparentadas daquelas perceptíveis na cultura brasileira. Na administração pública, talvez por suas peculiaridades, as características da cultura nacional estão mais visíveis. O setor público brasileiro é marcado por paradoxos como culturas calcadas em valores e comportamentos 
profissionais apartados do negócio e dos interesses do usuário, naquelas que orientam e promovem uma conduta profissional distinta do que é necessário para o sucesso organizacional. (CARBONE, 2000) Segundo DaMatta (1997) as instituições brasileiras, assim como o cidadão, estão submetidas a duas ordens sociais, uma é a universalista, burocrática, definitiva das agências públicas, e outra determinada pelas redes sociais e os recursos mobilizados e distribuídos por elas.

O servidor público no Brasil possui o estereótipo do trabalhador indolente. Segundo Campos (1999) a administração pública brasileira é penalizada por não poder se desfazer de servidores que não trabalham ou que atravancam o serviço. Os recrutamentos são condicionados, as carreiras são limitadas por promoções automáticas, os concursos além não compreendem todas as formas de seleção, possuem regras que podem ser adulteradas com facilidade. Nessas condições todos os servidores são considerados sob uma mesma perspectiva negativa, sendo colocados em um mesmo conceito o bom e o mau funcionário.

Para Carbone (2000) o valor do servidor público está na capacidade de conciliar interesses e apaziguar conflitos, aparentando o que não é. O empreendedor é exceção, para o brasileiro o jeito é a regra. É dizer que os preditores de sucesso na administração pública estão longe dos atributos do trabalhador empreendedor ousado, com alta capacidade técnica e de inovação. A partir dessa visão são qualificados todos os servidores, que também em razão disso acomodam-se às práticas usuais reforçando o ciclo vicioso, onde valem apenas os favoritismos e privilégios. Além disso, ocorre que também na esfera pública brasileira, muitas vezes, a escolha de pessoas que irão exercer funções públicas faz-se de acordo com critérios de relações pessoais e não de suas capacidades. (FREITAS, 1997) Assim nem todos estão aptos e predispostos ao serviço público em sua essência, mas são ali colocados para intencionalmente desvirtuar seus procedimentos e garantir a efetividade do funcionamento das redes relacionais.

De acordo com Chanlat (2002), o estereótipo de servidores com pouca predisposição ao trabalho, que estão primordialmente preocupados em perceber vantagens e privilégios, impregnou todo o serviço público. No entanto, nos últimos 20 anos a imagem do Estado e dos serviços públicos vem sofrendo importantes mudanças na sociedade. O novo funcionário precisa alcançar os mesmos padrões do servidor privado, ser competitivo e eficiente. Vieira e Carvalho (2003) concordam e enfatizam que o servidor atual deve prestar serviços à comunidade, ser eficiente e não desperdiçar recursos. Essas novas perspectivas oferecem alento aos novatos, que ainda sofrem pressão da cultura pública para adaptação ao perfil 
pejorativo do servidor, mas que por sua vez, não concordam com o estado das coisas por estarem já embebidos da cultura emergente.

Falando dos serviços públicos em geral, Chanlat (2002) acredita que a implantação do sistema gerencial nas administrações governamentais causará forte impacto no trabalhador. Em decorrência da implantação do novo modelo de gerência pública orientada para o desempenho e para a produtividade pode-se observar uma maior carga de trabalho e maior pressão por parte dos usuários. Também está visível que há grande apelo em aumentar a responsabilidade do servidor, no entanto, em razão da peculiaridade do serviço público, a hierarquia e a falta de autonomia apresentam-se como contraditórios ao grau de imputabilidade que o novo sistema quer impor. Há que se considerar que também os funcionários públicos recompõem parte do prescrito para cumprir suas tarefas diárias. Dessa forma a implementação do novo sistema exigirá penosos esforços primeiramente na cultura organizacional, para conscientização do servidor da nova realidade a aceitação gradual do novo estilo gerencial.

Chanlat (2002) demonstra que pelas últimas duas décadas os servidores públicos sofreram com o discurso sobre sua ineficiência, fraca produtividade e foram questionados sobre sua utilidade. Isso, somado às críticas da imprensa e ao meio dos negócios denegriu a auto-imagem desse trabalhador. O reconhecimento, segundo Dejours (1990: 1993) apud Chanlat (2002) está no íntimo do prazer e sofrimento no trabalho. Neste sentido a identidade profissional fica afetada em razão, principalmente, das condições precárias de trabalho quanto aos meios de produção, mas também, da descrença da comunidade de uma forma geral. O que vale é que os novos ventos trazem uma possibilidade de mudança na cultura nacional e a partir daí quem sabe, poderão ocorrer mudanças significativas no sistema de administração pública brasileiro que resgate o servidor como trabalhador necessário ao desenvolvimento do país.

Ainda segundo Chanlat (2002), com a implementação do modelo gerencial ao serviço público, sobrevieram os contratos temporários, a terceirização e a fragmentação de equipes de trabalho, fatores que afetam a qualidade do serviço apresentado. Em conseqüência disso perde-se uma característica fundamental do setor que diz respeito à segurança no emprego, condição necessária para a manutenção da neutralidade e da independência do trabalhador. A estabilidade no emprego no serviço público sempre foi valor apreciado para o recrutamento de pessoal, no entanto, no Brasil, esse mesmo atributo torna-se fonte de acomodação do servidor estabilizado, mais que pressuposto de neutralidade e independência. 
A implantação do gerencialismo, por fim, afeta a ética do serviço público. As qualidades que indicam um bom servidor como dedicação, integridade, igualdade de tratamento, características da burocracia, permitem despersonalizar o trabalhador distanciando a pessoa do cargo ocupado. Já o novo sistema prevê para o setor público a aplicação das regras de mercado, ou seja, a prevalência dos interesses pessoais, do lucro, da produção. (CHANLAT 2002) No Brasil a conscientização ética do serviço público acompanha o aumento dos escândalos envolvendo suas instituições. Paulatinamente, vão sendo criados nichos de respeitabilidade e com a aceleração dos discursos de transparência e legalidade vem crescendo a pressão do consumidor para que se desenvolvam atitudes menos passionais nos serviços prestados.

As organizações púbicas diferem das empresas privadas em algumas peculiaridades que segundo Pires e Macêdo (2006, p. 96) são; “apego às regras e rotinas, supervalorização da hierarquia, paternalismo nas relações, apego ao poder, entre outras". Neste sentido Schall (1997) apud Pires e Macêdo (2006) afirma que na distinção entre a organização pública e a privada pesa o fator descontinuidade administrativa que aplica ao setor público características específicas como: projetos de curto prazo, duplicação de projetos, conflitos de objetivos, administração amadora.

Considerando as características da burocracia brasileira, a descontinuidade, o excesso de paternalismo, formalismo, clientelismo e etc. Oliveira (2007) obtempera que segundo Gouvêa (1994), para analisar a administração pública brasileira deve-se levar em conta fatores relevantes da história do Brasil colonial como a atração que o País exerceu como colônia de exploração, a centralização das decisões em Portugal, a força do poder local e o sistema de relações personalista.

Dessa forma de acordo com Oliveira (2007), de início, a partir da Independência, a composição do Estado Brasileiro era formada por uma diversidade de grupos com estratificação salarial, hierárquica e social diferenciados, não havia preocupação com a racionalização do Estado ou aplicação do modelo weberiano burocrático. A partir daí, é de se perceber que a burocracia formada a partir do governo Vargas possuía particularidades como o espaço de poder proveniente de recursos políticos; agências que garantirem status de prestígio e criarem laços de solidariedade de manutenção do espaço institucional e das vantagens funcionais; a possibilidade de aquisição de formação técnica e conhecimento especializado o que alargava o espaço de poder, e por fim, o treinamento inserido na tradição administrativa que separava a ação técnica e organizacional da ação política. (GOUVÊA , 1994 apud OLIVEIRA, 2007) 
Por volta da década de 1960 surgiu o modelo de administração para o desenvolvimento que objetivava a expansão da intervenção do Estado na vida econômica e social, a substituição dos funcionários estatutários por trabalhadores celetistas e a criação da administração descentralizada em substituição ao modelo organizacional do país então, caracterizado pela centralização de um complexo aparelho burocrático Já nos anos 1980 o desafio era criar e estabelecer sistemas administrativos que acelerassem o desenvolvimento e possibilitasse o uso eficaz dos recursos do país. . MARCELINO (2003) apud PIRES E MACÊDO (2006) No entanto, conforme Oliveira (2007), a partir da década de 1980, os problemas econômicos e a ineficiência governamental provocaram o descrédito da burocracia e debilitaram a imagem do servidor público.

Mais adiante, tentativas do Governo Figueiredo de descomplicação da vida dos cidadãos e das empresas por eliminação de exigências excessivas de documentos foram gradativa e pacientemente anuladas pela resistência de burocratas que perderam poder e pelos interesses cartoriais que perderam renda certa e fácil. CASTOR E JOSÉ (1998) Conforme se pode depreender do que já foi dito, consoante Oliveira (2007), a administração pública brasileira, sem que haja uma ordem de sucessão ou conflitos conceituais convive com três modelos administrativos: o modelo patrimonialista, o modelo burocrático weberiano e o modelo gerencial. Pois, como bem observado por Torres (2004) apud Oliveira (2007), o modelo burocrático puro, weberiano, que reconhece a impessoalidade, publicidade, especialização, profissionalismo, etc. não foi sequer verdadeiramente implantado no Estado Brasileiro.

Nas organizações públicas brasileiras o que ocorre na prática é a exacerbação das características da burocracia weberiana. Contrariamente ao que vislumbrou Weber em sua obra, o agravamento das propriedades do modelo gerou críticas ao formalismo, ao apego às regras e ao grande número de níveis hierárquicos e transformou a Burocracia em sinônimo de lentidão, entraves, falta de objetividade, desencontro de informações, enfim, tudo o que não funciona. (OLIVEIRA, 2007)

Segundo Castor e José (1998) a criação de privilégios corporativistas, as práticas de favorecimento e de clientelismo, e até a corrupção pura nas organizações públicas são fomentadas pela autonomia operacional dessas organizações. Nesse mesmo sentido Tavares (1996) ao avaliar as relações de poder na administração brasileira, assegura que elas geram burocracia, desinteresse, excesso de normatização, regras e procedimento de controle o que prejudica o funcionamento da máquina. E ainda, de acordo com Pires e Macêdo (2006), por serem geridas pelo poder público, as organizações públicas brasileiras apresentam-se vulneráveis à interferência política. 
Para Gaster (1999) apud Pires e Macêdo (2006), tanto os usuários como os prestadores de serviços públicos possuem pouca expectativa em relação ao que pode ser oferecido em termos de prestação de serviços público, em razão da baixa qualidade desses serviços, criando um ciclo de insatisfação e frustração de gerentes e cliente/cidadão. Pires e Macedo (2006) observam que as expectativas negativas quanto a possíveis mudanças do setor público, decorrem da percepção deste como lugar de apadrinhamento político, de favorecimento pessoal e privilégios que burla regras formais, restando o sentimento de iniqüidade e injustiça, decorrente da inconsistência entre o discurso e a prática oficiais.

As formas complexas e os múltiplos níveis hierárquicos característicos do desenho organizacional público permitem alto controle de movimentações e distribuição de empregos na lógica dos interesses políticos dominantes. As estruturas são estáveis e, por isso, resistentes à mudança e implantação de novas tecnologias. A administração pública por ser culturalmente influenciada política e administrativamente, reflete, como enfatizado anteriormente, características simultâneas de um governo patrimonialista, burocrata e corporativo. Pires e Macêdo (2006)

As características de decisões centralizadoras, de estrutura rígida e a não orientação para $\mathrm{o}$ atendimento das necessidades dos cidadãos, eficácia ou efetividade foram absorvidas pela cultura das organizações públicas. Em razão disso, elas são avessas a inovações as quais mesmo consideradas de sucesso no setor empresarial, sucessivamente são implementadas nessas organizações sem que sejam levados em conta os objetivos e os valores da administração e são, conseqüentemente, fadadas à frustração. Pires e Macêdo (2006)

Saraiva (2002) citando Castor (1997) e Kliksberg (1994) enfatiza que a administração pública reage lenta e insatisfatoriamente às mudanças econômicas e sociais dando visibilidade a distorções e deficiências. A burocracia não garantiu rapidez, boa qualidade, ou custo baixo para os serviços prestados ao público, contrariamente a administração é lenta, cara, autoreferida, e pouco ou nada orientada para o atendimento das demandas do cidadão.

De acordo com Carbone (2000), apesar de recente, a história da administração pública brasileira possui características próprias onde os trabalhadores precisam possuir habilidades diplomáticas nas suas relações de trabalho, para não provocarem divergências com a administração pouco competente dos gestores. São as relações de estima e os jogos de influência os verdadeiros indicadores de poder no Brasil. Assim sendo, o alto índice de burocracia existente no funcionamento do Estado unifica as condições de trabalho e de organização do trabalho do setor público, que tende a oferecer idênticas condições laborais para funcionários de diversas organizações em razão da vinculação de suas decisões a uma 
autoridade externa à organização. (PIRES E MACEDO, 2006) Pereira (1996) apud Pires e Macêdo (2006) diz que a estabilidade dos servidores públicos fomenta a precarização do serviço público pela forma como é entendida no Brasil, é dizer que a ineficiência, a desmotivação, a falta de disposição para o trabalho não são puníveis por demissão.

Outra característica que imprime ao funcionalismo público um caráter específico é o fato de coexistirem na mesma entidade dois corpos funcionais: $O$ corpo permanente é formado pelos trabalhadores de carreira, cujos objetivos e cultura foram formados no seio da organização, e o não-permanente é composto por administradores políticos que seguem objetivos externos e mais amplos aos da organização. (MARTELENE, 1991 apud PIRES E MACÊDO, 2006) Da mesma maneira, Gouvêa (1994) apud Oliveira (2007), afirma que as práticas do patrimonialismo persistem atualmente, apesar do esforço de universalização do acesso à administração Pública. A ideologia clientelista e empreguista é ainda visível na comparação entre funcionários admitidos por concurso e os extranumerários, contratados sem concurso e por indicações pessoais.

Oliveira (2007) enfatiza que sucessivas tentativas de modernização da administração pública foram iniciadas a partir do estabelecimento da administração burocrática, em substituição ao patrimonialismo, daí seguiram-se os movimentos de reorganização do aparelho estatal pregando a flexibilização, desburocratização e mais recentemente o gerencialismo. Com o que concordam Pires e Macêdo (2006) quando acentuam que na tentativa de transformação e inovação da administração pública brasileira ocorre um embate entre o novo e o velho, é dizer que as forças do mundo contemporâneo encontram obstáculos na dinâmica e na burocracia enraizadas nas organizações.

Do mesmo modo, segundo Castor e José (1998), a história da administração pública brasileira é constituída a partir de lutas constantes entre as tentativas de modernização e a resistência da burocracia formalista. Assim, de um lado os interesses econômicos retrógrados, conservadores e politicamente influentes, cúmplices da burocracia, de outro correntes modernizantes com seus próprios aliados políticos e empresariais. Um a perpetuar o controle social e os privilégios e outra exigindo novas missões para o Estado. As sucessivas tentativas de modernização da máquina administrativa brasileira tiveram seus avanços reduzidos ou suprimidos pelas reações dos setores conservadores e tradicionalistas da burocracia, para citar alguns exemplos: a introdução dos modelos autárquicos; a criação do DASP, a utilização do modelo empresarial privado na administração estatal, a tentativa de introdução dos conceitos sistêmicos de gestão públicas (Decreto Lei 200/67) e a privatização das empresas. 
Os autores afirmam ainda, que embora algumas organizações tenham passado por todos esses eventos, eles não são necessariamente seqüenciais e sucessivos, ao invés disso, eles aconteceram por sobreposição onde instituições preexistentes não foram extintas, mas transformadas, mascaradas em capacidade inovadora. Dessa forma, as forças de modernização continuam a criar arranjos e improvisar soluções jurídico-organizacionais para contornar as regras paralisantes da burocracia tradicional. (CASTOR E JOSÉ, 1998)

Isso ocorre, de acordo com Castor e José (1998) porque as propostas de modernização brasileiras ocupam-se das estruturas prescindindo da reforma das teorias dominantes da burocracia. Os esforços da administração são mais alterações de nomenclatura e reacomodação de unidades internas, mais maquiagem, do que reformas propriamente ditas. E nesse sentido defendem que a sucessão de reformas e resistência é perversa, pois enfatiza na sociedade os sentimentos de desamparo e frustração em relação ao sistema de administração pública e torna sempre urgente a necessidade de ações efetivas e concretas que solucionem os graves problemas administrativos no Brasil. Pires e Macêdo (2006), dispõem que neste embate as ações inovadoras, que tentam imprimir nas organizações públicas brasileiras a cultura de flexibilização e de gestão empreendedora, esbarram nas dificuldades de implementação decorrentes da rigidez estatal.

No momento, a administração pública está lentamente sendo levada a priorizar tanto atendimento das necessidades de regulação como a prestação de serviços aos cidadãos, utilizando-se para isso o incentivo aos programas de flexibilização da gestão, permitindo à máquina um contorno mais barato, ágil e receptivo a inovações gerenciais e a autonomia administrativa. SILVA (1994) apud SARAIVA (2002) 


\section{Método}

Nesta seção será realizado o delineamento da presente pesquisa. Serão destacados os métodos e técnicas adotadas na execução das atividades, o instrumento utilizado na coleta de informações e os procedimentos de análise final das informações obtidas.

\subsection{Tipo de Pesquisa}

Segundo Schein (2007) para o levantamento de informações acerca da cultura organizacional de uma empresa, deve-se proceder entrevistas em grupo, pois são as pessoas que no coletivo armazenam as idéias e os valores que norteiam o comportamento da organização. É a partir da percepção coletiva que melhor se captam os elementos da cultura organizacional. A técnica de entrevista bem se presta nestas investigações por produzir grandes quantidades de informações na identificação de fatores de avaliação que ao serem relatados evocam novas contribuições de outros membros do grupo propiciando o embasamento do estudo da cultura organizacional.

Observando-se os ensinamentos do autor foi realizada investigação, por meio de aplicação de entrevistas semi-estruturadas em grupos focais para pesquisar componentes da cultura organizacional do Tribunal de Contas do Distrito Federal. Neste sentido, pode-se dizer que se trata de um estudo de campo. Pode-se ainda afirmar, de acordo com Cervo e Bervian (2002), que o presente estudo é bibliográfico, descritivo e exploratório. A pesquisa bibliográfica é caracterizada por oferecer explicações sobre um assunto a partir de referências teóricas publicadas, por meio das quais pode-se conhecer e avaliar contribuições já existentes, sejam elas culturais ou científicas, acerca de um tema específico. Quando não há manipulação dos dados ou informações recolhidas sobre fatos ou fenômenos tentando-se apenas estabelecer relações, análises ou registros sobre freqüência, conexões, natureza e características, diz-se que se trata de pesquisa descritiva. Finalmente, uma pesquisa será exploratória quando procura uma nova visão, percepções ou idéias sobre um determinado fenômeno com a intenção conhecer o elemento estudado. Neste caso objetiva-se a descrição da situação para descobrir relações existentes entre as informações obtidas.

A pesquisa na área da cultura organizacional está consolidada e desperta grande interesse teórico e prático, pois, no universo organizacional, novos estudos trazem novas contribuições e perspectivas de análise compatíveis com as exigências de inovação do atual cenário. (FREITAS, 2007) Assim sendo, conhecer a cultura organizacional permite ao 
analista ou ao consultor antecipar conseqüências e escolher se elas são desejáveis ou não. Descrever as certezas compartilhadas e por que elas são mantidas serve para que o grupo determine se elas continuam funcionando no contexto atual. (SCHEIN, 2007) A finalidade da pesquisa em cultura organizacional abre um leque de possibilidades para utilização de métodos e instrumentos que devem ser atentamente avaliados em sua consistência com o foco do estudo.

A pesquisa é ainda qualitativa pela natureza das variáveis estudadas, de acordo com Richardson (1999) pois tem a intenção de compreender os significados e características do fenômeno por meio de documentos e entrevistas e não por medidas numéricas. Neste sentido, esses estudos procuram mais construir que aplicar conceitos já definidos, trabalham com amostragem intencional reduzida ao invés de grandes populações e tendem a refletir as experiências subjetivas e não testar hipóteses pré-definidas. (ZANELLI, 2002)

Para efeito da presente pesquisa a abordagem qualitativa se justifica por ser o estudo da cultura organizacional complexo e possuir nuances que possibilitam a compreensão de peculiaridades do comportamento humano que por meio de tratamento de dados numéricos poderiam passar despercebidos.

\subsection{Amostra}

A pesquisa compreendeu um total de 18 sujeitos distribuídos em 3 grupos focais, numa amostra não probabilística intencional, dentre os servidores do Tribunal de Contas do Distrito Federal. Os critérios utilizados na seleção dos participantes foram:

a) tempo de casa entre servidores antigos (com mais de 13 anos de casa)

b) ocupantes de cargos estratégicos;

c) servidores da área meio, ocupantes ou não de cargos em comissão;

d) servidores da área fim, não ocupantes de cargos em comissão.

Procurou-se por meio dessa amostra abarcar um grupo, ainda que reduzido, representativo do total de servidores do Tribunal de Contas. Os requisitos estabeleceram uma tentativa de considerar contribuições de um grupo estratégico, todos servidores efetivos de nível superior, da alta administração da área fim de atuação do órgão, os quais ocupam cargos em comissão e vivenciam diretamente as influências externa e internas. O outro grupo foi intencionalmente produzido com servidores efetivos de nível superior, não comissionados que trabalham na execução do controle externo propriamente dito, e que por isso sofrem o impacto das influências externas e internas. E por fim, o grupo de servidores efetivos de nível 
médio, ocupantes ou não de cargos em comissão que executam suas tarefas na área meio da instituição, que possuem uma visão intermediária das influências externas e externas. A amostra foi montada na intenção de produzir visões diferenciadas sobre a organização captando informações relevantes das áreas meio e fim e percepções de profissionais engajados no cumprimento da missão do Tribunal.

A faixa etária variou entre 58 e 36 anos, 8 participantes eram do sexo masculino e 10 do sexo feminino, todos com formação superior, 14 com pós-graduação, servidores efetivos do Quadro de Pessoal dos Serviços Auxiliares do Tribunal de Contas do Distrito Federal.

A escolha foi realizada de forma intencional e os contatos para participação foram realizados pessoalmente por meio do desenvolvimento de uma rede de relacionamento para totalizar o plano previsto de 18 participantes.

\subsection{Instrumento}

Na coleta de informações foi realizada pesquisa bibliográfica com o intuito de limitar e justificar as contribuições do presente estudo. Considerando-se a natureza da pesquisa, o assunto e sua complexidade a delimitação da abrangência do estudo é fundamental na constituição e definição dos instrumentos a serem utilizados. O tipo de documentos bibliográficos consultados abrangeu livros, periódicos, revistas científicas, anais de congressos científicos, todas publicações idôneas indicadas na coleta de informações acerca da cultura, cultura organizacional e cultura organizacional no setor público.

O principal foco da coleta de informações foi em artigos atualizados sobre os temas afetos à cultura organizacional, tanto em publicações impressas como virtuais. Os principais recursos de busca, via internet, utilizados foram Google, portal Capes e Scielo e a procura se deu a partir de referências das próprias publicações consultadas, baseada nas indicações de acessibilidade e idoneidade dos artigos encontrados.

Tomando por base a pesquisa bibliográfica previamente elaborada foi realizado o estudo de campo. Assim buscou-se principalmente levantar impressões acerca do fenômeno cultura organizacional partindo-se do pressuposto de Freitas (2007) quando obtempera que de uma forma geral as pesquisas e abordagens que, tomam a cultura como uma metáfora, enfatizam mais as questões de poder, controle social ou ideológico e a construção de vínculos e de imagem, ou seja, os aspectos mais conceituais e políticos da organização. Acatada essa definição, foi realizada uma adaptação do Modelo Simplificado para se levantar indícios da cultura de Órgãos Públicos elaborado pelo Orientador, Professor Dr. MARCUS VINICIUS 
SOARES SIQUEIRA e procedidas entrevistas, previamente agendadas, em grupos focais constituídos por 6 pessoas cada, em horário e local de trabalho, em sala ampla, arejada, reservada, coletando-se as informações por meio de anotações e gravações devidamente autorizadas pelos participantes, garantindo-se a confidencialidade do material coletado. O uso de gravadores facilita a transcrição dos dados assim como permite esclarecimento de dúvidas durante a análise das informações, servindo ainda como documento para consulta. As entrevistas aconteceram nos meses de setembro e outubro de 2008.

Neste caso a opção por entrevistas em grupo se justifica tendo em vista a possibilidade que oferecem de apreensão de perspectivas coletivas sobre os valores e crenças que permeiam o comportamento humano na organização. Segundo Schein (2007), a maneira menos trabalhosa de colher elementos de uma cultura é reunir grupos e discutir assuntos abrangentes sobre o funcionamento de diversas unidades da empresa e observar onde está o consenso. Para ele por meio do grupo são descobertas as áreas de interesse para a pesquisa, a intensidade dos sentimentos em relação às áreas de interesse e a centralidade das diversas certezas compartilhadas.

O conteúdo das entrevistas foi previamente definido tomando-se por base as possíveis variáveis relacionadas ao poder, controle social ou ideológico e a construção de vínculos e de imagem. Foram englobadas questões que pudessem responder ao problema da pesquisa. $\mathrm{O}$ Roteiro de entrevista encontra-se acostado em anexo e está composto por 13 perguntas as quais têm o objetivo de levantar indícios da cultura organizacional do TCDF. As questões são abertas de forma a delinear somente o caminho e o limite da resposta, abrindo-se espaço para complementações e colaborações de outros participantes conforme a situação que se apresente no momento. O uso da técnica de entrevista é recomendado tendo em vista a ampla possibilidade de produção de dados, percepções, opiniões e experiências e a relativa facilidade de identificação e coleta das informações necessárias além da perspectiva de surgimento de novas questões.

\subsection{Análise dos resultados}

Para análise dos resultados obtidos por meio das entrevistas, foi utilizada a técnica de análise de conteúdo baseada na teoria de Bardin (1977) a qual pode ser caracterizada como um método empírico de inferência, que destaca o que não é dito e não está aparente, o que permanece escondido na fala do interlocutor. A descrição do conteúdo por esse método se dá por forma e fundo verificando a freqüência na forma e a aparição de símbolos no fundo. $\mathrm{O}$ 
mecanismo divide em categorias os conteúdos resultantes do texto, no entanto, não se preocupa com a descrição deles, mas com sua relação com outros contingentes teóricos sobre o assunto investigado, traduzindo em uma ordem os significados antes embaralhados.

Bardin (1977) propõe a execução do método em três fases. Inicialmente o tratamento das informações revela-se inferencial e interpretativo de forma que o pesquisador conheça o texto com o qual vai trabalhar tirando daí impressões e orientações para o embasamento na tomada de decisão quanto aos temas mais relevantes para responder o questionamento do problema de pesquisa. Conhecidos os temas ou documentos a serem analisados, cria-se um conjunto desses documentos que a autora denomina Corpus. A orientação para a composição do Corpus é de que não se deixe de fora elementos quando não houver razão para que isso aconteça, a amostra de documentos deve ser representativa em relação ao universo total de informações, os documentos devem ser homogêneos a partir de critérios específicos de escolha e estar em condições adequadas de fornecimento de informações para solução do problema.

Finalmente, a etapa de exploração consiste na transformação dos dados brutos em material passível de significação e validação. Assim, são constituídas categorias a partir de diferenciações e agrupamentos sob critérios previamente definidos. As categorias devem reunir registros com elementos comuns sob um mesmo título, sob os critérios semânticos, sintáticos, léxico ou expressivo. Primeiro os elementos são isolados e a seguir condensados nas categorias.

No presente estudo, para efeito de análise, na definição das categorias os elementos foram classificados por meio dos critérios léxicos e expressivos pelos assuntos políticos, de controle, de pessoas e institucional. 


\section{Apresentação de Resultados}

Os achados da pesquisa foram trabalhados de acordo com a análise de conteúdo proposta por Bardin (1977), daí emergiram 4 grandes categorias compostas cada uma por temas relacionados aos traços ou indícios da cultura organizacional do Tribunal de Contas do Distrito Federal segundo descrito a seguir:

Categoria POLÍTICA: essa categoria expressa traços da cultura nacional que influenciam a cultura organizacional do Tribunal de Contas do Distrito Federal, de acordo com a percepção dos sujeitos. Os dados obtidos revelam valores, comportamentos e ou crenças pessoais e coletivas presentes na cultura organizacional do órgão as quais se acredita que advenham da cultura nacional em sentido amplo.

Tema: NACIONAL - diz daquilo que a cultura do Tribunal absorve da cultura nacional, sob a forma de influência em comportamentos, crenças e valores.

18 - "nossa sociedade não é muito preocupada com o interesse público, com a coisa pública"

18 - "é a tal da falta de cumprimento da norma"

13 - "isso aí está tudo dentro desse negócio de ter uma imagem de poder associada a ele."

13 - "cultural nosso aqui de se ter vantagem em tudo"

16 - "a injustiça ocorre e não tem uma justiça efetiva para punir, para dar exemplo"

18 - "atuação bem independente, bem autônoma, ela é na realidade afetada por esse processo de escolha."

18 - "então para mim prevalece muito o coronelismo"

11 - "Uma rede, um movimento que se faz para reagir"

15 - "é para mim eu acho que essa coisa do brasileiro mesmo, essa falta de visão coletiva"

7 - "falta uma consciência... ou uma maturidade política"

6 - "Você quem está falando, aqui é do gabinete de fulano"

6 - "na base do acordo, na base do conchavo e não é diferente aqui."

$1-$ "cultura brasileira de ver sempre negativamente qualquer experiência..."

6 - "quem quer acessar o poder ou é para usar ou é para servir."

6 - "Quem manda aqui sou eu."

1 - "foco deles não é necessariamente servir à sociedade, mas satisfazer o meu interesse."

1 - "entrar aqui e para ser o funcionário público que antes eu condenava lá fora."

5 - "essa falta de compromisso eu acho que isso é mais amplo é cultural."

5 - "padrinhos ou por apadrinhamento político ou por apadrinhamento pessoal ou por grupos de amizades."

5 - "cultura do se dar bem."

5 - "muito arraigado a questão de oportunismo, não é. É a questão do...muito a questão de QI."

Tema: INDIVIDUAL: exprime percepções dos entrevistados acerca de um traço do personagem brasileiro, que está presente também nos servidores do Tribunal.

13 - "o interesse público geral não pelo que a pessoa pode fazer pela sociedade."

11 - "Você é mais técnico, você é passional, não é essa idéia do coletivo, do todo."

5 - "não trabalha, mas eu não vou... hoje estou aqui, amanhã eu não estou"

11 - "cada um que carregue o seu piano."

5 - "colegas que gostam de trabalhar contra você." 


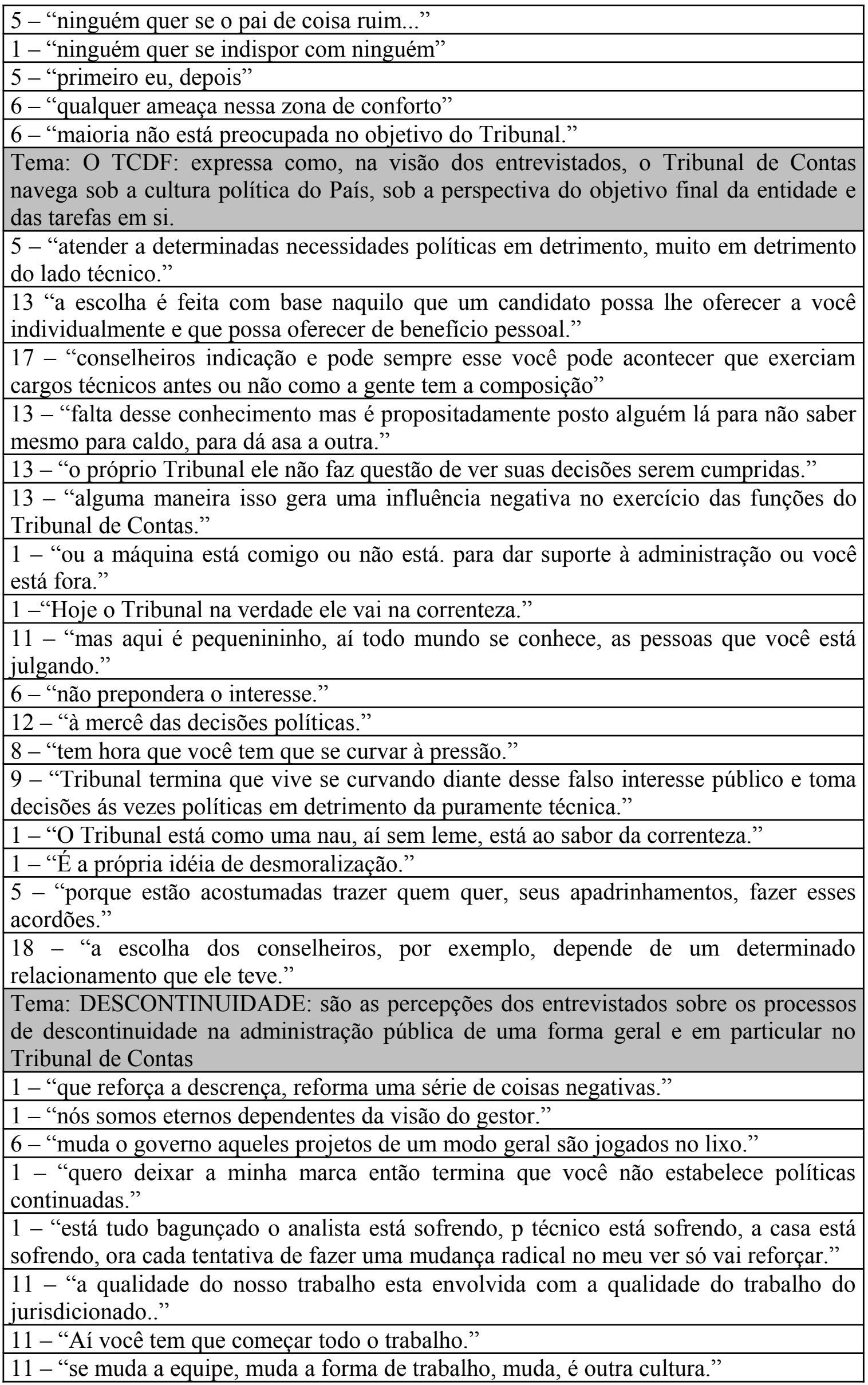


12 - "Mas eu ficava estressada só de pensar eu ia mudar a presidência"

9 - "que cada dirigente ele tem uma postura própria dele, tem o seu jeito de administrar então diretamente os subordinados"

13 - "nós temos aí já tem de muitos anos é a mesma coisa a muito tempo, eu não tenho visto descontinuidade é administrativa."

Categoria: CONTROLE: Essa categoria exprime temas afetos às formas de controle que são utilizadas no Tribunal de Contas, às maneiras como o Tribunal se comporta, em que acredita e o que valoriza em termos de pressão no trabalho, pressão social, regrais informais, recompensas e punições.

Tema: PRESSÃO NO TRABALHO - exprime percepções quanto às pressões decorrentes do trabalho no Tribunal de Contas

1 - "Como é que eu assimilo a pressão? Eu odeio eu acho um absurdo, eu estou para não agüentar mais..."

6 - "porque tem prazo tem tudo para cumprir não tem jeito sabe, então assim."

5- "eu tinha que dar conta chegou a um ponto que quando eu adoeci."

1 - "que a gente é obrigado a assumir."

6 - "série de situações que você não criou, que você não tem responsabilidade com aquilo, mas..."

11 - "você tem 2 dias para examinar e o pessoal tem feito..."

9 - "o servidor que trabalha com a gente ele passa o ano todo engajado com a coisa de produtividade."

9 - "Você tem que dar jeito, você tem que resolver, isso você tem $12 \mathrm{mil}$, isso é uma vergonha para a sociedade."

13 - "eu ultimamente eu não tenho pressão.

14 - não tem pressão mesmo, a gente não trabalhado sob pressão..."

11 - "conciliar produção para participação dos processos do Tribunal eu sempre tenho essa dificuldade."

15 - "Eu falo gente porque o povo lá esta carregando piano."

17 - "gente quarta é quarta trabalha sob."

Tema: PRESSÃO SOCIAL: fala das percepções sobre as formas de pressão social utilizadas por colegas de serviço sobre o rendimento no trabalho.

8 - "no padrão até mesmo porque que ele é pressionado pelos outros que não produzem."

7 - "ô fulano trabalha menos, senão a gente fica mal na fita ."

9 - "Ele vai muito bem durante um período, durante alguns anos e diria até, depois os outros, a pressão externa começa a vir dos colegas mas ele vai se adequando."

12 - "fazer melhor para sociedade do que o trabalho que ele ta fazendo."

13 - "limitação de produção, eu vejo uma norma não escrita de que... tem padrões de produtividade que colegas não podem exceder aquilo porque constrange os demais."

13 - "trabalhar menos. Tem lugar que a pessoa é orientada a não correr demais não pode andar um pouco mais lento, não se estresse."

Tema: REGRAS: exprime a percepção dos sujeitos sobre o cumprimento de normas formais e informais

1 - "Horário, a certeza de que não vai dar certo."

5 - "os chefes te dão recompensas, não escrita, já ele não pode ter dar alguma"

11 - "os relatórios de trabalho cada um é feito de uma forma não teve uma obrigação das pessoas de usar e tudo."

12 - "é, mas não tem assim uma norma estabelecida."

12 - "Não, não foi em campo, não tem lugar nenhum que está escrito que ele tenha que 
ir a campo."

11 - "que a gente não cumpre... têm algumas questões, férias a gente nega."

13 - "eles até cumprem as regras gerais de uma forma... eles vão fazer uma auditoria eles planejam, eles têm papel de trabalho, eles não cumprem algumas formalidades e não exercem todos, eles trabalham numa mesma formatação, mas via de regra eles trabalham dentro do processo que se diz de auditoria, mas se ele fosse pegar esse trabalho e estabelecesse um período ele ia ver que não funciona desse jeito."

13 - "o Tribunal praticamente trabalha com normas não escritas "

13 - "eu acho que o Tribunal é muito de normas não escritas."

Tema: RECOMPENSA: o tema trata de percepções acerca do sistema de recompensas e reconhecimento por trabalhos realizados no Tribunal de Contas

11 - "porque não tem como destacar o trabalho e tem analistas excelentes que não tem como ter recompensa."

6 - "em relação à quantidade de serviço e de trabalho tem gente aqui que às vezes não faz nada mais o chefe não libera não pode sair mais cedo e tal."

5 - "mas na hora que você quer o reconhecimento é... eu particularmente, não vejo acontecer não, de forma generalizada, não."

6 - "uma falta de uma política de reconhecimento o T para mim não tem (...) também não tem uma política de reconhecimento voltada a te retribuir adequadamente (...) então a retribuição vem mais do viés político."

E - "e o reconhecimento viria com...

11 - ele viria a partir de uma..... de exercer alguma função no Tribunal."

13 - "aqui se dá às vezes, se dá cargo como forma de promoção pelo desempenho."

18 - "doou sangue põe lá nos assentamentos do camarada, ah que põe de propósito ele vai ficar lá nos assentamentos, ninguém sabe."

6 - "pegar um periodozinho de folga ali que acaba sendo recompensador."

6 - "é uma recompensa isso o fato de você folgar."

Tema: PUNIÇÃO: o tema expressa a dificuldade percebida pelos participantes da pesquisa quanto a instrumentos de punição de abusos.

3 - "sim porque nós temos cargos políticos esses não têm como mexer. O efetivo você tem sim como punir de uma certa forma tem."

16 - "aí o chefe faz o quê?"

5 - "vira casa da mãe Joana mesmo."

5 - "pune, pune, tiram cargos, trocam de setor."

6 - "e não davam trabalho para ele não davam nada o cara ficou lá 6 meses cozinhando, chegava no horário e ficava cozinhando."

5 - "se tem horário e a pessoa não cumpre."

12 - "A falta de punição acho que não tem esse apavoramento, acho, isso alimenta o comodismo de algumas pessoas de não cumprir as regras, pessoas que não querem saber de horário, não querem saber de produção."

11 - "impunidade, não tem se eu trabalho se eu fiz 10 processos ou seu eu fizer $1 \mathrm{eu}$ vou ganhar o mesmo salário vou ter a mesma regalia de salário."

11 - "nós não temos punição o Tribunal."

11 - "mas eu já trabalhei com analista que vou te contar dava .... e não tem punição."

9 - "e quando ocorre a punição é mudar o servidor de lotação, muda o setor dele, isso é punição?”

11 - "a punição acaba sendo aquele servidor que é transferido."

6 - "a pessoa passa uma semana sem vir no Tribunal e não tem conseqüência nenhuma." 
Categoria PESSOAS: a categoria abrange as formas de relacionamento entre as pessoas e entres as pessoas e a instituição, expressas em temas relacionados às relações interpessoais, à postura do servidor e sobre os comportamentos gerenciais.

Tema: RELAÇÃO INTERPESSOAL: o tema diz da percepção dos participantes da pesquisa quanto ao relacionamento entre a pessoas dentro do Tribunal de Contas

13 - "olha que eu já briguei com gente... se o cara se aborreceu, aborreceu longe de mim."

15 - "algumas pessoas que carregam os pianos apesar de elas se darem bem com as chefias elas tendem depois a romper."

13 - "mas eu não tenho eu nunca percebi isso."

11 - "todos tem um bom relacionamento, inspetor, diretor, analista, técnico, pessoal de apoio a gente tem uma troca de respeito muito grande."

11 - "há respeito, há coleguismo de uma forma geral. há companheirismo."

Tema: ESTRATIFICAÇÃO: o assunto desse tema surgiu da percepção de alguns participantes da pesquisa e revela a existência de estratificação social entre categorias funcionais do Tribunal de Contas.

6 - "as coisas são muito bem estratificadas eu estou falando de categorias funcionais, aqui tem analista que não se mistura de jeito nenhum porque ele é analista (...)discriminação real mesmo entre o pessoal de carreira fim e o pessoal de carreira meio, inclusive o pessoal de carreira meio que é de nível superior, é uma questão que para mim é muito claro isso."

1 - "pessoas que ao cumprimentarem não são respondidas surgiu formalmente, é mais grave do que nós imaginamos, então tem um certo elemento entre certas categorias que só respondem a cumprimentos que sejam de pares."

6 - "todos nos tratam com diferença."

1 - "o cara está sofrendo tanto, a discriminação, ele embarcou na discriminação, ele embarcou."

1 - "o cara não fala com ela porque ele é analista e ela é técnica."

6 - "você é analista, aí o colega respondeu não, eu sou técnico. Não tem um analista para conversar comigo aí não."

Tema: EQUIDADE E JUSTIÇA - expressa as percepções quanto aos sentimentos de equidade e justiça entre os servidores do Tribunal de Contas

11 - "quem trabalha mesmo, quem tem aquela responsabilidade, interna ali, que quer cumprir o prazo. Os que não têm, não fazem então assim..."

1 - "não há por parte das pessoas a percepção de justiça organizacional."

1 - "eu percebo o seguinte carência por instrumentos para poder diferenciar pessoas você tem."

5 - "é injusto para quem está, e cômodo para quem não."

1 - "Esse é o lado injusto desse serviço então se tem um histórico quando você faz muita coisa além do normal e do anormal."

5 - "eu saí da inspetoria eu amava o trabalho que eu fazia na inspetoria porque não é justo, é injusto o que acontece lá."

4 - "essa equidade não pelo menos no nosso setor não é, não existe não."

6 - "e aí é iniqüidade mas não é só do meu setor, eu conheço outro setor que tem problemas desse tipo."

13 - "Quer dizer há dois pesos e duas medidas aqui."

13 - "o tratamento não é realmente equânime a gente viu aí aqueles que não têm interesse em produzir e não querem trabalhar, na verdade são beneficiados porque continuam sem trabalhar, continuam ganhando." 
3 - "Isso é muito injusto recebe como quem produz."

Tema: FALTA DE COMPROMISSO: elenca a percepção de servidores quanto ao comprometimento de alguns trabalhadores com os resultados apresentados pelo Tribunal de Contas

13 - "pelo menos nos últimos, há algum tempo atrás: não andem tão depressa que não tem necessidade."

5 - "quem não tem esse espírito ou comprometimento, tanto faz você trabalhar ou não você vai ganhar no fim do mês a mesma coisa."

6 - "tanto faz o cara trabalhar como não trabalhar no final do mês ele vai receber o salário como quem produz."

12 - "se ele quiser... ele recebe o salário dele do mesmo jeito, então assim de..."

15 - "porque tem pessoas que não trabalham nunca e que ficam lá, poucos se comprometem com prazos com não sei o que, não sei o que, começa a passa tudo para eles."

Tema: POSTURA DO SERVIDOR: diz, de uma forma geral, como o servidor público é percebido pelos entrevistados.

6 - "reflexo na visão que o próprio servidor tem de não apostar e aí fica nessa posição

no que se refere àquele campo de comodidade, tranqüilidade, fica dessa forma."

10 - "aqui a gente convida...

9 - ninguém vai..."

11- "Ninguém quer se envolver, a gente tem essa questão ainda de, o problema não é meu."

11 - "ninguém quer participar do comitê de qualidade"

15 - "quando há uma indignação forte as pessoas acabam se unindo assim no negócio da ponte."

15 - "Então houve uma indignação geral e que culminou na gente ir lá no plenário de preto para mostrar a indignação, você lembra?"

13 - então a gente tem uma cultura de que a gente é meio parcimonioso, meio e a gente acaba aceitando passivamente algumas coisas...

J - "de organização, de organização de não... se ver as coisas como sendo parte de uma organização, as partes de um todo, a gente vê individualmente, a gente não tem isso realmente."

18 - "meu modo de ver o nível profissional."

1 - "A busca pela estabilidade, função e estabilidade. Não se entra no serviço público necessariamente com essa visão de eu vim para trabalhar."

1 - "e essa de tirar proveito que estou aqui e para ser o funcionário público que antes eu condenava lá fora. Só quero meu bem-estar."

13 - "as pessoas que aqui estão são bem qualificadas mas a gente faz coisas, que não, que ... melhor do que todos.

10 - "o problema é aliar a capacidade técnica como comprometimento, todo mundo é capaz."

5 - "eu vejo o chefe pedindo pelo amor de Deus para o cara trabalhar ou fazer e parar de ver as questões pessoais para trabalhar um pouquinho."

7 - "o cara vai chega atrasado e não está nem aí, ele pode chegar atrasado, pegar um processo facilzinho ele não tem aquele comprometimento às vezes com o ..."

7 - "é que é o que eu tô dizendo a pessoa que fala muito em ética em valores em princípios será que essas pessoas estão sendo éticas mesmos?"

7 - "a gente pode dizer talvez falta de comprometimento com o resultado institucional."

12 - "é e poucos se engajam nessa meta... está nem aí..." 
12 - "Não estou generalizando, mas têm pessoas que não se engajam."

18 - "falta que os servidores sejam impregnados daquelas idéias de compromisso com a coisa pública, de dedicação ética."

13 - "entrou todo mundo naquele espírito de servidor público de 15 anos de 30 anos de serviço já."

1 - "ingressam no setor público já vem com esse pressuposto. Parecem muito empolgados, mas logo, logo, questão de poucos meses se percebe que na verdade boa parte já veio procurando um lugar para se acomodar em função da estabilidade."

Tema POSTURA GERENCIAL: aborda as impressões sobre como atuam os gestores no Tribunal de Contas

18 - "falou na gestão que realmente, veja só, não há nem gestão, não existe cobrança como é que existe pressão. Na verdade nós temos um problema gravíssimo aqui de gerenciamento."

18 - "de cumplicidade, o chefe não mexe com o cara e o cara fica na dele tb não vai acusar o chefe."

3 - "isso é problema de gestão, entendeu? é um caso muito."

9 - "para mim isso tem uma causa assim, que é característica, é a falta de um instrumento de medir, essa diferença entre as pessoas, então como todo mundo."

13 - "Pois é porque não, aí é que está, a gente não faz porque não é exigido. O dia que alguém exigir e mandar ferro, a gente vai ter que fazer, queira ou não queira."

16 - "mas o, aí o diretor ele vai falar o seguinte: eu vou me indispor com ele e estão me pressionando eu preciso disso para ontem, então eu vou passar para ela."

13 - "É um problema então cultural do Tribunal também de gestão, que as pessoas que exercem o cargo de chefia. Lógico que tem instrumento, mas não se aplica."

16 - "o chefe, todo mundo, todo mundo acaba sendo meio bonzinho, aqui com todo mundo."

13 - "isso aí é uma deficiência uma cultura gerencial."

3 - "é... o que que acontece com o Tribunal hoje? Quem não trabalha, não tem controle nenhum, tem a estabilidade também, trabalhar para quê? Meu chefe não me chama atenção, eu posso chegar a hora que eu quiser, eu posso fazer do jeito que eu quiser."

Categoria INSTITUIÇÃO: compreende a percepção dos participantes da pesquisa quanto à imagem do Tribunal, o que a instituição busca, o que valoriza, o que oferece e em que condições de trabalho.

Tema: IMAGEM: relata percepções dos servidores entrevistados sobre aspectos que identificam o Tribunal de Contas do Distrito Federal

6 - "o cara lá fora que olha do Tribunal para dentro ele vê o Tribunal com reservas porque o Tribunal..."

6 - "então o que se vê na televisão sobre o Tribunal de Contas, não são aspectos positivos Onde é que você trabalha? Ele dá meia volta, porquê quando ele fala que trabalha no Tribunal... daquele órgão que a gente vê que não significa nada que não presta, que entrava."

1 - "então tem missão, visão e objetivos, não tem valores não tem."

8 - "as pessoas desconhecem qual a missão do Tribunal,"

18 - "Tribunal, não era bem conhecido nem da população nem do próprio corpo administrativo, a administração pública do DF daí esse trabalho de abrir e procurar se aproximar desse pessoal, da estrutura administrativa..."

13 - "a verdade é a gente tem culturas mas a questão de visão de instituição, nós não temos visão, assim cultura de ver a coisa como uma instituição que é um conjunto de todos esses quadradinhos que fazem parte de seu organograma." 
7 - "eu acho que um grande valor aqui todo órgão de fiscalização um grande valor é da ética, da moral, não se pode num órgão que fiscaliza você ter É uma coisa positiva." 12 - "quando um analista vai para o trabalho aí quando ele vai até ele pensa assim (...) ele se engaja, ele faz o trabalho pensando realmente na sociedade, pensando em defender direito público e tal."

9 - "eu acho que a maior missão, como órgão fiscalizador, é a nossa defesa, não só do erário, mas também do servidor público e da sociedade de uma forma geral. a missão nobre do Tribunal, essa defesa do erário e do próprio servidor e conseqüentemente da sociedade."

8 - "eu acho que sim, acho que o próprio nome do Tribunal, todo mundo tem interesse que seja resguardado, seja respeitado, é com uma imagem imaculada do Tribunal."

13 - "eu acho que o que une... o nosso produto final ele está claramente delimitado eu acho que é essa natureza auto-explicativa aí do negócio."

17 - "o nosso objetivo quanto a gente instrui é que esteja tudo ok, que o Tribunal dê legalidade."

17 - "O fim da instituição a missão eu acho que ninguém tem isso na cabeça não

14 - só quando está trabalhando."

18 - "é aquela visão burocrática, retrograda, atrasada apesar de todos avanços, nós servidores trabalhamos com um princípio da prestação de contas sabe."

13 - "a ação do Tribunal não é transparente (...) Tribunal ter processo sigiloso, mas a casa tem dificuldade para tratar as coisas de forma aberta, ampla."

13 - "T existe, perante o jurisdicionado, cada vez com menos pesar com menos respeito, a gente que vive fazendo auditoria a gente percebe isso."

17 - "eu vejo nitidamente o que você estava falando no julgamento das contas quando vc aprova contas não sei se vocês aqui já tiveram oportunidade

15 - com muitas ressalvas."

13 - "a partir dali piorou muito a situação porque se tornou tão pedagógico, que a sensação de impunidade parece que ficou mais aflorada, entendeu."

15 - " a gente notava um certo respeito, assim porque o Tribunal parece que queria realmente ser."

16 Ele quis aproximar mais, pelas reuniões com os jurisdicionados explicar o que era o Tribunal o que se fazia aqui. O objetivo aí era que os jurisdicionados aprendessem essas coisas e se reduzisse a quantidade de problemas que aqui chegavam, só que aí vc encurtou a distância, aquele medo, não existe mais."

Tema: DISCURSO X PRÁTICA: levanta as percepções sobre o distanciamento entre a teoria e a prática nas ações internas e externas do Tribunal de Contas

17 - "Então você sabe que até as próprias decisões do $\mathrm{T}$ de controle externo muitas delas não de aplicam para o que a gente faz aqui dentro."

13 - "é a distância entre os discursos e as práticas, eu acho que há de um tempo para cá uma tendência de desacelerar as atividades de fiscalização."

13 - "aí é uma outra cultura, vou traduzir: faça o que eu digo não faça o que eu faço."

13 - "É a divergência entre o discurso e a prática o que se fala ele é muito moderno, pertinente é válido, no discurso mas o que se faz não é alinhado a isso aí."

13 - "mas do ponto de vista prático nunca sai nada do papel, quando sai, sai de faz de conta, não tem aquela seriedade na execução, não tem aquele negócio."

18 - "Quando na verdade isso aí é formal mais na prática a gente ta mesmo e defendendo nossos interesses."

7 - "discurso ótimo, agora na prática fazer e demonstrar."

11 - "é buscado te um retorno para a sociedade, uma ligação só que na prática as 
pessoas desconhecem isso, em termos institucional é bem elaborado"

8 - "exige uma postura e uma ética e um não sei nem sempre o comportamento dele é de acordo com o comportamento que ele exige do fiscalizado."

1- "Um traço da cultura organizacional em grande medida parecer que boa parte do discurso é ele não significa que aqueles que estão reclamando queriam mudanças."

Tema: CULTO À QUANTIDADE: o tema descreve a percepção dos participantes sobre a produção de processos na qual se prioriza a quantidade, sem preocupação com qualidade ou resultado obtido.

1 - "o número de estoque ainda são muitos que garante uma produtividade média anual quantidade de processos razoavelmente boa."

13 - "E a cultura da quantidade e não realmente trabalha com

14 - não de resultados, abrir mão pela quantidade."

15 - "e se preocupa mais com números, números que processos que entrou, números decisões exaradas, número de não sei o que, ou seja, a ênfase ainda é nos processos, não é resultado."

9 - "Essa a gente sente que há, essa eu diria, não sei se é crítica mais há um.... não causa prazer trabalhar com essa cobrança de aliar a qualidade com a quantidade."

9 - "gente vive sempre correndo atrás de quantidade e que acham que tem que prevalecer a qualidade à quantidade e eu sou uma defensora de aliar qualidade e quantidade."

Tema BENEFÍCIOS: revela a percepção dos servidores quanto às vantagens de trabalhar no Tribunal de Contas

1 - "acho que idealismo de alguns patriotas de alguns servidores que trabalham porque gostam"

1 - "Aqui só é bom gente, porque a gente fecha os olhos para isso e a gente tenta unir aos outros como amigos."

11 - "as pessoas gostam de uma forma geral da instituição, gostam até do horário, salário."

16 - "porque aqui ganha relativamente bem não é? Estuda não faz outro concurso e aí o que acomoda também não é? Acho que é..."

15 - "o que equilibra aqui são as outras vantagens que o Tribunal oferece, ah o horário é bom, tem recesso e aí você começa a pesar, as coisas que melhoram sua qualidade de vida fora daqui, você tem mais férias, você tem recesso, você tem salário bom e tal, horário."

18 - "o salário bom."

14 - "não é o salário."

1 - "nós já tínhamos um horário privilegiado porque tínhamos $1 \mathrm{~h}$ de tolerância."

1 - "O que é valorizado, compartilhado por todos aqueles aspectos legais que nós temos no Tribunal os que nos são favoráveis pessoalmente, horário, possibilidade disso, possibilidade daquilo."

Tema PARTICIPAÇAO: reúne percepções acerca dos processos decisórios e de participação do servidor do Tribunal de contas

E - "e as decisões? Como são tomadas as decisões a participação faz parte da cultura organizacional?

10 - não.

11 - não, é o que eu falo as decisões nos processos.

E - e a gerencial?

11 - não, a gente ainda fica sabendo de coisa assim vou perguntar alguma coisa para $\mathrm{J}$ : ah! Mas o que está acontecendo? ah! Mas a gente não está sabendo de nada." 


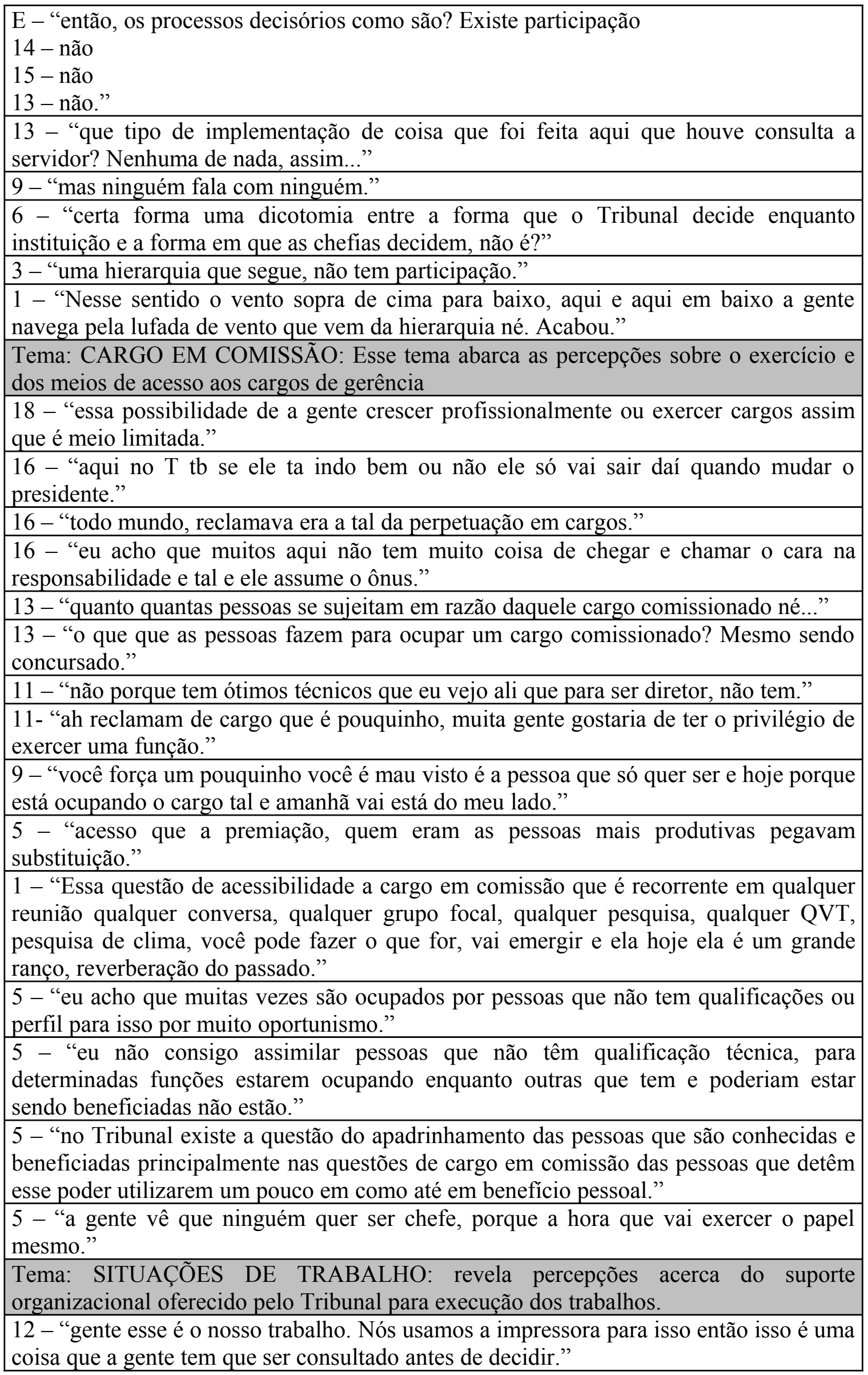


5 - "eu gostaria de estar numa seção atuante que eu contasse com profissionais para estar respondendo essas coisas todas. Que é o maior interessado não dá condições para a gente aprender, responder mais e mais com mais eficácia com mais eficiência as coisas que são necessárias."

15 - "muita gente lá da terceira sai do Tribunal inclusive, porque assim as chances de evolução na carreira são pequenas."

5 - "tem que escrever o que não quer... eu não tenho esse perfil.."

5 - "quando eu caí, quando eu adoeci, ninguém me deu respaldo, me mandaram embora da função, me mandaram para inspetoria com o seguinte recado: problema."

12 - "então são umas falhas assim que sabe a gente, nós somos os usuários nós temos as necessidade o corpo técnico tem as necessidade então tem determinadas áreas que elas tem que trabalhar para atender as necessidades do corpo técnico e isso não acontece,."

Tema: SENTIDO DO TRABALHO: o tema remete às percepções e vivências do corpo técnico quanto a realização no trabalho e quanto ao fruto do seu trabalho.

16 - "porque isso aí não vai, processo vai a plenário, se ele achar que não é, que tem que relevar, que tem que isso, tem que aquilo, não adiantou nada."

18 - "Não se deve esperar que o aspecto político vá deixar de existir lá no pleno. Lá eles têm outras funções não estou falando que sempre decidem corretamente não, sem beneficiar ninguém não, não é isso."

9 - "a decisão do plenário é soberana não é?

12 - a gente tem que olhar a parte técnica e passar as informações técnicas para o plenário

9 - a decisão é política, às vezes não é?"

11 - "que está tendo uma desvalorização do trabalho

6 - "acaba esse lado do pessimismo de que as coisas não dão certo que a instituição em si tem defeitos em relação ao seu objetivo final, não é?"

9 - "é que há predominância do político ao técnico, então eu acho que isso às vezes ocorre mas eu acho que o equilíbrio sempre é bem..."

10 - "uma coisa que une muito é o resultado da fiscalização, que ele trabalha não é, se der resultado não é, agora, se o plenário não encampa, ou ocorre, não que ele tenha que encampar, mas se eles acham que a justiça não foi feita...

9 - desmotiva não é?"

12 - "já tem uma consciência de que a gente, o corpo técnico a gente faz o que a gente pode"

15 - "porque na verdade não se busca mesmo o resultado e isso fica..."

15 - "é um T que existe não é tem esse discurso de ah nossa missão é isso tal, mas no final das contas, ai fica mandando a gente trabalhar intensamente não é para pegar as coisas mas no final das contas é aquela coisa política"

15 - "na contra-mão não é da digamos do foco em resultado a gente já se acostumou em não pensar em resultados, não vamos fazer a nossa parte aqui e esquece o resto do processo. Porque no início eu sempre fui meio frustrada sabe aquilo de ficava acompanhando, assim você entra em depressão. Então eu acho que uma cultura é assim ah faça a sua partezinha ali e esquece que não vai dar em nada"

16 - "os servidores podem fazer o trabalho deles, sabendo que podem não encontrar o mesmo fim quando for para plenário. Então fica difícil, você ter estímulo, acreditar, porque você nunca sabe o que que vai resultar então..."

15 - "se acostuma não vou fazer a minha parte não importa o resultado, não é que você faça que é pior, no meu caso não é que eu faça pior"

13 - é tudo que a gente cobra dos outros (...) mas então eu falei assim para ele o que 
importa para mim é o resultado da ação do Tribunal e isso eu não vejo." 11 - “o que você acredita está lá, está assinado embaixo, está registrado no processo, e uma opinião diferente pode acontecer..."

1 - "eu vejo na cultura é o traço da cultura organizacional do não vai dar certo."

1 - "Muito chefe lá do outro lado não veja conseqüência do trabalho, do trabalho do analista quanto ao produto final."

3 - "ela trabalha assim muito, mas ela se sente frustrada porque ela quer trabalhar, ela quer desenvolver um trabalho, entendeu? Quando chega lá na frente, chega lá no plenário, chega lá na frente o trabalho dela é barrado, por quê? porque acho que a frustração maior é você não ver o resultado"

5 - "quanto ao resultado eu tenho a seguinte coisa na minha cabeça eu fiz minha parte, está aqui, daqui para frente..."

1 - "aqueles que conhecem na verdade tem frustração em face do não atingimento comum que a sociedade enxerga, não vê atuação, não vê retorno, não vê realização"

9 - "A cada fiscalização ele vai, ele faz tudo diferente, ele é estimulado a fazer outra, ele vai com a mesma vontade para fazer (...) acredita de novo é um exercício de... de crença para levar o Tribunal, mas eu vejo isso lá depois de uma fiscalização onde os resultados... não é o esperado"

11 - "é isso que eu ia te falar, e aí alguns são passionais com o processo: você pára de ser passional... aqui não é justiceiro."

11 - "então sofre porque está com a expectativa dele, talvez se a gente visse o Tribunal como esse órgão não só técnico, mas político, você aceitasse certas decisões que causam sofrimento."

13 - "Nós que estamos realmente cada vez, desmotivados, sei lá."

17 - "e isso causa perda de credibilidade, que por sua vez causa a desmotivação da pessoa que trabalha com isso."

5 - "gente, sabe um martírio... você chegar com o edital nas mãos às vezes com coisas que você não tem nem elementos, nem como, nem como você começar porque não tem nada conhecido, ou porque não tem instrumentalização para fazer e tem que sair 3, 4 dias uma análise botando o seu nome, entendeu, submetendo a um plenário e lá na frente ainda está sujeito a estar sendo questionado, porque você aqui dessa forma e tal. Porque as coisas foram conduzidas daquela forma."

5 - "você faz um trabalho e você está no microfone sendo escrachado publicamente, sabe, pelo relator seja por quem for porque você fez uma informação que contrariou interesses."

5 - escrachado? Vários, e a gente dica escutando, é testemunha!

6 - "É falou, não compete, alerte a ICE que não compete a ela entrar no mérito do voto do relator, não compete à ICE."

12 - "é uma série de acusações assim, sem o fundamento e a gente vai ter que buscar tudo, parar tudo para ir atrás, da justificativa."

11 - "houve um destrato público de servidores"

13 - "e o Tribunal, nesse caso a presidência de então, não nos deu, a nossa divisão pelo menos não nos deu o apoio devido na situação (...) no Tribunal os de fora têm mais valor do que nós aqui dentro. Tudo o que é dito lá a priori é verdadeiro, o que a gente diz aqui... talvez não."

13 - "Então eu acho que outra cultura e da falta de apoio no exercício, se é que isso é cultura não é, a falta de apoio nas, no exercício das funções de controle aqui."

14 - nas funções técnicas

15 - “assim eu não me, isso é comigo, eu não me sinto... eu me sinto valorizada pelo 
meu chefe direto sabe, mas eu não me sinto valorizada pelo, pelo T 15 - "no processo da ponte a gente foi elogiado foi, deu em alguma coisa, nada defenderam a gente quando o cara nos atacou? Não."

13 - "no momento que o elogio, igual medalha não é fica uma coisa banalizada, aquele quem tem mérito de ter ganho a medalha, não se sente." 


\section{Discussão dos resultados}

Dos achados da pesquisa pode-se extrair algumas conclusões que demonstram possíveis indícios da cultura organizacional do Tribunal de Contas do Distrito Federal. Na primeira grande categoria identificada, a política, surgiu o tema Nacional que abrange aspectos da cultura nacional presentes, de alguma forma, pela percepção dos entrevistados, na cultura organizacional. Os traços mais marcantes estão revelados nas falas dos sujeitos e dizem respeito à falta de interesse e consciência com a coisa pública, à utilização da política em detrimento da competência técnica no acesso aos cargos da alta administração, à pouca efetividade na atividade fim, tendo em vista a falta de punição, a certeza de que nada vai acontecer, aos acordos e conchavos, ao oportunismo, ao tirar vantagem em tudo, ao se dar bem, tudo isso conjugado com o uso das redes de relacionamento em benefício dos segmentos sociais, econômicos e políticos dominantes. Esse tema ainda contém o reflexo da visão negativa que se têm do servidor público em geral, associado ao fato, de que lá estando, existe a tendência ao comportamento que antes era combatido e àquele relacionado ao "Você sabe com quem está falando?” muito usado conforme a percepção dos entrevistados.

No tema Individual foram destacadas falas relacionadas ao culto ao individualismo presente, na visão dos participantes, na cultura do TCDF. Esse tema encerra que os servidores têm uma preocupação predominantemente relacionada aos seus próprios benefícios e à preservação de uma zona de conforto que envolve as atividades da instituição, de forma que não há adesão às propostas de mudanças, mesmo quando resultantes de demandas dos próprios servidores, quando isso pode significar prejuízo desse pensamento individualizado.

O tema TCDF se refere às percepções dos entrevistados sobre aspectos relacionados à forma de composição do Plenário e à absorção das influências nas atividades do Tribunal. Está presente o sentimento de que as coisas funcionam no Tribunal em consonância com as condições políticas locais e nacionais, sob a alegação de que o Pleno é composto por indicação política, pela proximidade local com os gestores, foco das fiscalizações e, também porque, de alguma forma, os gestores revestem processos na suposição de necessidades do interesse público.

A Descontinuidade administrativa também foi tema da categoria Política, ela compreende, basicamente, as preocupações ou referências dos entrevistados sobre esses processos no Tribunal e na administração local, que exercem grande influência nas atividades de retrabalho e nas programações futuras de implementação de sistemas de trabalho. Enfatiza as situações em que o administrador quer deixar sua marca, não encapando projetos já 
iniciados por outros, mudando, às vezes radicalmente, os processos de trabalho existentes o que causa sofrimento, estresse e uma sensação de bagunça e de imaturidade organizacional. Paradoxalmente, a descontinuidade, para os servidores que atuam na área fim do Tribunal, apesar de ser preocupação constante, parece estar, de alguma forma, estabilizada nos últimos anos. Mesmo havendo mudanças na Presidência, os processos de trabalho internos da área fim vêm sendo preservados nos revezamentos políticos. No entanto, quando a descontinuidade atinge os fiscalizados, isso, quase sempre, significa retrabalho e novas atividades para o corpo técnico.

Na categoria Controle, o tema Pressão no Trabalho indica que na percepção dos servidores entrevistados a pressão para o trabalho atinge em especial algumas unidades, determinados tipos de serviço e diferentes servidores. Revelando atividades sazonais, atuação de gerentes e conciliação entre tarefas e eventos do Tribunal.

Nesta categoria surgiu o tema pressão social. Esse tema refere-se apenas as atividades de controle externo, fim do Tribunal, nesta área de atuação restou evidenciado que na percepção dos interessados, de forma muito forte, o corpo técnico é pressionado socialmente para trabalhar aquém das necessidades e possibilidades da administração. Assim tanto as próprias pessoas vão se ajustando naturalmente ao ritmo estabelecido de forma mediana ou são literalmente informadas pelos colegas de trabalho de que as coisas devem andar de forma mais lenta.

Ainda na categoria controle, emergiu o tema Regras que diz respeito à percepção de cumprimento de normas informais. Dentro das regras que existem, mas que não são plenamente cumpridas, existem as questões de horário e de gozo de férias. Dentre as não escritas foram estabelecidas formas de recompensa aos servidores e os processos de trabalho das unidades da área fim, os quais não são uniformes funcionando de acordo com a vontade ou necessidade de específica de cada servidor ou unidade.

O tema Reconhecimento se fez presente na categoria Controle. Na percepção dos pesquisados não há no Tribunal políticas de reconhecimento de servidores. Dessa forma foram criadas formas de recompensa que vão desde liberação de cumprimento de horário e folgas a elogios e premiações por meio do exercício de encargos e cargos em comissão oferecidos de modo particular por gerentes ou pela própria administração.

O tema punição, em consonância com as formas de recompensa percebe-se como inexistente. Para os entrevistados não há forma de punição para o mal servidor, que não tem compromisso com horário ou produção. Percebe-se que esse servidor fica passando de lotação em lotação punindo, ele próprio, de certa forma, os colegas das unidades por onde passa ou 
porque têm que trabalhar por ele ou porque não possuem suas regalias. De outra forma existe também a percepção de punição por meio de mudança indesejada de lotação ou de retaliação pela não atribuição de trabalho, para os que são mais comprometidos. A figura da Corregedoria surge como uma forma de punição quando faz acusações sem clareza e a retirada de encargo e cargo em comissão pune aqueles que têm esse benefício.

$\mathrm{Na}$ categoria Pessoas os dois primeiros temas são contraditórios e referem-se a duas situações com percepções opostas, no entanto, tão significativas que não são excludentes entre si. O primeiro tema caracteriza a percepção dos servidores dos grupos focais representantes da área fim do TCDF e diz respeito ao bom relacionamento entre as pessoas de uma forma geral, baseado em circunstâncias de coleguismo, respeito e companheirismo. Havendo tão-somente pequenos ressentimentos entre aqueles que se percebem trabalhando mais que os outros. Paradoxalmente, na área meio, há relatos muito consistentes de percepção de segregação funcional no Tribunal, mencionando rusgas, discriminação e subjugação entre servidores de categorias funcionais de níveis educacionais diferentes.

Outro tema dessa categoria diz respeito à percepção de equidade e justiça entre os servidores da Casa. Neste quesito os relatos afirmam que na percepção dos servidores não há tratamento equânime entre os servidores, ao contrário, há relato de injustiças, perseguição, cumprimento diferenciado de horários e cargas semanais, na distribuição de trabalho e falta de reconhecimento por trabalhos realizados, assim como falta de punição por serviços não realizados.

A categoria possui o tema relacionado ao Compromisso com o trabalho que encerra que, nas percepções dos entrevistados, existem servidores no Tribunal que não exercem adequadamente suas atribuições e que percebem suas vantagens e benefícios como os servidores que têm compromisso com os objetivos do Tribunal. Muito próximo desse o tema Postura do Servidor fala da falta de interesse e de participação em eventos do Tribunal, do não engajamento em atividades de produção e atingimento de metas, falta de preocupação com os resultados e da dificuldade dos gestores em buscar a participação de alguns servidores. $\mathrm{Na}$ percepção dos entrevistados tais servidores têm preocupações muito pessoais e são pouco cooperativos. Por outro lado, há a visão muito clara de que o corpo técnico é altamente capacitado e bem qualificado, no entanto, parece que quem ingressa no Tribunal vem à procura de estabilidade e exercício de cargo em comissão sem o foco no resultado institucional.

O tema Postura Gerencial enfatiza que na percepção dos participantes da pesquisa há no Tribunal falta de gerenciamento e controle das atividades e de instrumentos de medida que 
diferenciem os servidores entre si. Os relatos indicam que ocorre leniência no tratamento de servidores não comprometidos na cobrança de produtividade, por medo de se indispor com colegas ou por cumplicidade entre chefes e subordinados.

A categoria Instituição engloba o tema Imagem que diz respeito à percepção do Tribunal como instituição perante os servidores e a sociedade. Sugiram discussões sobre os aspectos negativos que contaminam a percepção da sociedade quanto à efetividade dos Tribunais de Contas e no que diz respeito aos trabalhos de fiscalização propriamente ditos. Já o servidor do Tribunal deseja que essa imagem seja resguardada e procura por meio de seu trabalho técnico impor respeito entre os jurisdicionados. Nesses casos o corpo técnico se ressente da aprovação de processos com ressalvas os quais favorecem a visão pejorativa do órgão fiscalizador.

A diferença entre o Discurso e a Prática tornou-se tema na categoria Instituição. Esse tema revela que na percepção dos colaboradores da pesquisa a instituição como órgão fiscalizador estabelece regras e faz cobranças distanciadas das práticas do próprio órgão. Assim o comportamento exigido nem sempre é adotado, existindo um discurso interno que é diferente do externo. Internamente falta seriedade na execução do discurso moderno, pertinente e válido.

O Tribunal, de acordo com a percepção dos entrevistados cultua a quantidade de trabalhos executados em detrimento da qualidade ou da efetividade no resultado. Assim em razão do número alto de processos de aposentadoria mantém sempre altas as porcentagens de processos examinados, pareceres e decisões exaradas.

O tema Benefícios foi percebido como sendo indicado pelos salários compatíveis com aqueles aplicados ao segmento, horário e recesso que permitem maior qualidade de vida pessoal. Surgiram ainda percepções de idealismo e vínculos de amizade como forma de vantagens de se trabalhar no Tribunal.

A Participação nos processos decisórios foi percebida como inexistente, prevalecendo a hierarquia, a unidade de comando com decisões impostas de cima para baixo na cadeia, das quais se toma conhecimento e providencia-se sua execução. Nos processos decisórios internos das unidades, parece haver a percepção de tentativa de envolvimento dos servidores em algumas seções isoladas.

Quanto aos Cargos em Comissão percebe-se que seu exercício vem como premiação pela boa atuação técnica. No entanto, é fala recorrente o fato de que bons técnicos não necessariamente são bons gerentes, e assim, o Tribunal perde o técnico que passa a ter atribuições outras, e fica sem o gerente por falta de competência ou qualidade gerencial. Desse despreparo resultam dificuldades de imposição de ritmo de trabalho, ocorrendo 
sobrecarga tanto para o gestor, como para os seus melhores colaboradores. Ocupar cargo em comissão para o servidor do Tribunal parece ser um privilégio de poucos, que se sujeitam às condições e assim se eternizam no exercício das funções.

O tema Condições de Trabalho aborda questões percebidas pelos servidores entrevistados como de responsabilidade do Tribunal, que não são oferecidas para que se desenvolvam os trabalhos de forma eficiente. As queixas estão relacionadas com o suporte às necessidades do corpo técnico, às poucas chances de evolução na carreira, às exigências políticas e a falta de apoio em ocasiões de necessidades pessoais dos servidores.

Finalmente o tema Sentido do Trabalho diz respeito principalmente às atividades da área fim do Tribunal. Na área meio revela-se uma percepção geral de que as coisas não dão certo porque o Tribunal, em relação ao seu sentido último, não alcança os resultados esperados pelos servidores e pela sociedade. Porém na área fim essa falta de foco no resultado gera no corpo técnico estresse, raiva, adoecimento e desmotivação, tendo em vista que o trabalho técnico perde o seu valor quando a decisão é política. Neste sentido o servidor trabalha com uma visão fragmentada do todo, deslocando o fruto do seu trabalho, o relatório de fiscalização, do resultado final do processo sobre o qual o Plenário tem decisão soberana. $\mathrm{Na}$ percepção dos sujeitos da pesquisa o corpo técnico se esforça na apresentação dos resultados da fiscalização de forma técnica, porém se desprende do resultado ou do acompanhamento do processo pela possibilidade de não dar em nada. O corpo técnico se ressente ainda de estar constantemente sofrendo questionamentos, às vezes públicos, sobre sua competência para atuação em processos específicos pelos quais não têm controle sobre as decisões finais. 


\section{Conclusão}

De uma forma geral, e à luz da cultura nacional, os indícios predominantes da cultura organizacional do Tribunal de Contas, na perspectiva dos participantes da pesquisa podem ser os descritos a seguir: interesse pessoal em detrimento do interesse coletivo, decisões políticas em detrimento das decisões técnicas, pouca efetividade na atuação da administração pública, hierarquia e unidade de comando, impunidade, descontinuidade, uso de redes relacionais em acordos, conchavos e oportunismo. Cultura do se dar bem em tudo e de usar o status ou poder para obter vantagens individuais, distanciamento entre discurso e a prática, normas informais, estratificação social, falta de equidade e justiça. Quanto aos servidores marcam o individualismo, a falta de compromisso e o trabalhar menos, sem esforço almejando sempre a premiação na indicação política para o exercício de cargos em comissão. Todos dizem respeito a valores, crenças, simbolismos, comportamentos e vínculos pessoais e institucionais de alguma forma presentes na cultura nacional.

Assim, de acordo com o que se pode observar pelas informações colhidas no decorrer da pesquisa, o Tribunal de Contas ainda segue o padrão predominante presente no funcionalismo público geral, em termos de patrimonialismo, burocracia e corporativismo. $\mathrm{O}$ fato é que as características do órgão como centralização de poder, favorecimentos políticos, distanciamento entre o discurso e a prática e desvalorização do servidor permitem o controle e movimentação pela lógica estabelecida na cultura brasileira. Repete-se o ciclo de insatisfação tanto com a prestação do serviço, como pelo engessamento político que bloqueia qualquer tentativa de modernização e inovação gerencial e de autonomia para o órgão.

São valores do Tribunal de Contas: O técnico faz o que pode, mas a decisão é política; o corpo técnico é capacitado, mas carece de compromisso; o relacionamento entre as pessoas é bom, mas sofre influência do preconceito e discriminação entre as categorias funcionais; existem dois Tribunais um composto pelo Plenário e outro pelo corpo técnico, pode-se perceber aqui o Brasil dual, permissivo, que onde opostos não são excludentes, mas participantes de um contínum que se mistura dependendo da pessoa ou do fato a ser analisado.

Fica nítida a percepção que os entrevistados têm de que as coisas no Tribunal dependem da rede relacional existente na cultura nacional. Seja pelo poder, pelo status, por amizade ou família, todas as regras podem ser abrandadas e os compromissos descumpridos ao sabor da vontade de quem melhor navega.

Paradoxalmente, uma crença que aparece nas pesquisas é a de que o Tribunal tem orgulho do seu trabalho técnico, neste caso, em detrimento dos resultados obtidos, pode-se 
vislumbrar que o servidor acredita no seu próprio trabalho e o realiza pensando no resguardo da coisa pública e do nome do Tribunal.

$\mathrm{Na}$ evolução dos trabalhos restou observado que o sentido do trabalho para o corpo técnico se perde quando as decisões são tomadas de forma política, na aprovação de contas com ressalvas, na legalidade de processos com ranhuras técnicas, na distinção entre o que se faz e o que se cobra. O sentido do trabalho para os servidores da área fim pode vir a ser um bom assunto a ser tratado em pesquisas futuras. Porque a crença de que, mesmo bem feito, o seu trabalho não alcança os resultados necessários, levam a outra crença forte, presente no Tribunal e na cultura nacional, de que as coisas não dão certo, que não levam a nada. Isso cria descrença no funcionalismo, desvalorização do servidor e falta de motivação para o trabalho.

A impunidade como traço da cultura nacional se repete na visão dos participantes da pesquisa tanto nas decisões plenárias que favorecem os gestores que, propositadamente ou não, fazem mal uso do erário, como no tratamento diferenciado entre os servidores da própria casa. Outra percepção que se observa nos resultados da pesquisa diz respeito à pressão social que o bom servidor sofre na maneira como realiza seu trabalho. Se um servidor se destaca de alguma forma, ele é pressionado a se ajustar ao meio, assim é obrigado a trabalhar menos, mais devagar, para que os outros não sofram represálias. Esse fato pode ser relacionado com a aversão que o brasileiro tem ao trabalho. Holanda já dizia que o brasileiro no trabalho, não se esmera em rigor ou método, fazendo-o com desleixo e liberdade.

Também o pouco uso das regras escritas na execução das tarefas exibe um traço bem brasileiro de burlar as normas e de criar regras demais. Regras que já são criadas para não serem cumpridas abrindo um espaço entre o trabalho descrito e o trabalho real. São todas formas de sobrevivência do servidor brasileiro em seu meio de trabalho.

Dessa forma, traços da cultura nacional e das culturas organizacionais dos serviços públicos foram encontrados nesta pesquisa dando indícios da cultura organizacional do Tribunal de Contas. 


\section{REFERÊNCIAS}

Bardin L. Análise de conteúdo. Lisboa: Edições 70; 1977.

Brasil, Constituição Federal, art. 71,1988.

CAMPOS A. C. Administração pública: bloqueio e desenvolvimento. Revista de Administração Pública: Rio de Janeiro, v. 33 n. 6: 171-89, Nov/dez. 1999

CARBONE, P. P. Cultura organizacional do setor público brasileiro: desenvolvendo uma metodologia de gerenciamento da cultura. Revista de Administração Pública: Rio de Janeiro v. 34 n 2: p. 133-44, mar/abr 2000.

CARVAlHO, M.S.M.V; TONET H.C. Qualidade na Administração Pública. Rio de Janeiro, 1994, v. 28, n.2, abr/jun

CASTOR, B.V.J. e JOSÉ. H.A.A. Reforma e Contra-reforma: a perversa dinâmica da Administração Pública Brasileira. Revista de Administração Pública: Rio de Janeiro, v. 32 n. 6 p. $97-111$ nov/dez 1998

CAVENON N. R. Cultura organizacional: gerenciável, homogênea e quantificável? In: Bitencourt (org.). Gestão Contemporânea de pessoas: novas práticas, conceitos tradicionais. Porto Alegre: Bookman. Cap. 20, 438-452, 2004

CERVO, A.L. e BERVIAN, P. A. Metodologia Científica. São Paulo: Pratice Hall, 2004

CHANLAT, J. O gerencialismo e a ética do bem comum: a questão da motivação para o trabalho nos serviços públicos. VII Congresso Internacional Del CLAD Sobre la Reforma Del Estado y de la administracion Pública, Lisboa, Portugal, 8-11 Oct.2002

DAMATTA, R. A casa e a rua espaço, cidadania, mulher, e morte no Brasil Rio de Janeiro: Rocco, 1997

DAMATTA, R. O que faz o brasil, Brasil? Rio de Janeiro: Rocco, 2000

FERREIRA, M.C e ASSMAR, E.M.L. Cultura Organizacinal em: SIQUEIRA, M.M.M. et al. Medidas do comportamento organizacioal: ferramentas de diagnóstico e de gestão. - Porto Alegre : Artmed, 2008. Cap. 7.

FREITAS, A. B. Traços Brasileiros para uma análise organizacional em: MOTTA,P; CALDAS,M Cultura Organizacional e Cultura Brasileira. São Paulo: Atlas, 1997. P 38/54 
FREITAS, M. E. Cultura Organizacional: evolução e crítica. São Paulo: THOMSON, 2007.

FREYRE, G. Sobrados e Mucambos. São Paulo: Global, 2004

GEERTZ, C. A interpretação das culturas. Rio de Janeiro: Guanabara. 1989

HOLANDA, S. B., Raízes do Brasil. São Paulo: Companhia das Letras, 1999.

LARAIA, R. B. Cultura: um conceito antropológico. Rio de Janeiro: Zahar, 1997

MIGUELES C. P. O exercício do poder pelos administradores e a motivação dos empregados: algumas considerações teóricas sobre esta relação. Revista de Administração Pública: Rio de Janeiro, v. 33 n. 3: 113/138, maio/jun. 1999

MOTTA, P. Cultura e organizações no Brasil em: MOTTA,P; CALDAS,M Cultura Organizacional e Cultura Brasileira. São Paulo: Atlas, 1997. P 25/37

OLIVEIRA, C.G. O servidor público brasileiro: uma tipologia da burocracia. Revista do Serviço Público. Brasília 58 (3): jul/set 2007.

PIRES, J.C.S e MACÊDO, K.B. Cultura organizacional em organizações públicas no Brasil. Revista de Administração Pública: Rio de Janeiro 40 (1): 80 -105, Jan/fev 2006

PRATES M. A. S; BARROS B. T. o estilo brasileiro de administrar, sumário de um modelo de ação cultural brasileiro com base na gestão empresarial em: MOTTA,P; CALDAS,M Cultura Organizacional e Cultura Brasileira. São Paulo: Atlas, 1997. P 55/69

RICHARDSON, R.J. Pesquisa Social: métodos e técnicas. 3.ed. São Paulo Atlas: 1999.

ROBBINS, S. P. Comportamento organizacional. São Paulo: Pratice Hall, 2002 cap. 6 e 17

SARAIVA, L. A. S. Cultura Organizacional em Ambiente Burocrático. RAC, v. 6. p.1. p.187-207, jan/abr.2002

SCHEIN, E. H. Guia de sobrevivência da cultura corporativa. $2^{\mathrm{a}}$ ed. Rio de Janeiro: José Olímpio, 2007

SOUZA-DEPIERI,C. C. L. SOUZA, E. C. L. Empreendedorismo e cultura: Divergências e confusões conceituais; Encontro de Estudo sobre Empreendorismo e Gestão de Pequenas Empresas (EGEPE): Anais do IV EGEPE, 1, ISBN, 2005. 
TAVARES, F.P. A cultura organizacional como um instrumento de poder. Caderno de Pesquisas em Administração, v. 1, n.3 2º sem. São Paulo: 1996

VIEIRA, M. M. F.. CARVALHO, C. A. Organizações, instituições e poder no Brasil. Rio de Janeiro: FGV, 2003 Cap. 6 e 7

ZANELLI, J.C Pesquisa qualitativa em estudos da gestão de pessoas. Estudos de Psicologia, n. 7 p. $79-88,2002$

ZANELLI, J.C.; SILVA, N. Cultura Organizacional In: ZANELLI, J.C. BORGESANDRADE, J. E., BASTOS, A. V.B. (org.). Psicologia, Organizações e Trabalho no Brasil. Porto Alegre: Artmed, 2004. p. 407-442. 


\section{ANEXO \\ ROTEIRO DE ENTREVISTA PARA PESQUISA DE CAMPO}

1. Qual é a sua visão quanto à cultura política do país? Como ela influencia a cultura do TCDF?

2. Qual é a sua visão quanto à cultura organizacional do TCDF?

3. Como o TCDF reage às influências políticas externas?

4. Quais são os principais valores compartilhados pelos membros do TCDF?

5. As estratégias do TCDF são coerentes à missão e à cultura do TCDF?

6. O que une os membros da organização em torno dos objetivos organizacionais?

7. A cultura organizacional assimila pressões relacionadas à gestão ou há uma aversão quanto à pressão no trabalho?

8. Como as pessoas reagem aos processos de descontinuidade administrativa presentes no setor público?

9. Como as pessoas se relacionam como seus pares e com suas chefias e subordinados?

10. Como as pessoas se relacionam com a organização? Quais são as suas vivências de prazer e sofrimento no que tange à cultura organizacional?

11. Como as decisões são tomadas? A participação faz parte da cultura do TCDF?

12. A justiça organizacional, como equidade em termos de sistemas de recompensas e punições está presente na cultura organizacional? Há punição para abusos de poder? Eles fazem parte da cultura do TCDF?

13. Quais são as normas não escritas da organização? 